\title{
The Beneficial Effect of Melatonin in Brain Endothelial Cells against Oxygen-Glucose Deprivation Followed by Reperfusion-Induced Injury
}

\author{
Juhyun Song, ${ }^{1}$ So Mang Kang, ${ }^{1,2}$ Won Taek Lee, ${ }^{1}$ Kyung Ah Park, \\ Kyoung Min Lee, ${ }^{3}$ and Jong Eun Lee ${ }^{1,2}$ \\ ${ }^{1}$ Department of Anatomy, Yonsei University College of Medicine, Seoul, Republic of Korea \\ ${ }^{2}$ BK21 Plus Project for Medical Sciences and Brain Research Institute, Yonsei University College of Medicine, \\ 50 Yonsei-ro, Seodaemun-gu, Seoul 120-752, Republic of Korea \\ ${ }^{3}$ Department of Neurology, Seoul National University College of Medicine, Seoul, Republic of Korea
}

Correspondence should be addressed to Jong Eun Lee; jelee@yuhs.ac

Received 25 March 2014; Revised 7 June 2014; Accepted 20 June 2014; Published 14 July 2014

Academic Editor: Honglian Shi

Copyright (C) 2014 Juhyun Song et al. This is an open access article distributed under the Creative Commons Attribution License, which permits unrestricted use, distribution, and reproduction in any medium, provided the original work is properly cited.

\begin{abstract}
Melatonin has a cellular protective effect in cerebrovascular and neurodegenerative diseases. Protection of brain endothelial cells against hypoxia and oxidative stress is important for treatment of central nervous system (CNS) diseases, since brain endothelial cells constitute the blood brain barrier (BBB). In the present study, we investigated the protective effect of melatonin against oxygenglucose deprivation, followed by reperfusion- (OGD/R-) induced injury, in bEnd.3 cells. The effect of melatonin was examined by western blot analysis, cell viability assays, measurement of intracellular reactive oxygen species (ROS), and immunocytochemistry (ICC). Our results showed that treatment with melatonin prevents cell death and degradation of tight junction protein in the setting of OGD/R-induced injury. In response to OGD/R injury of bEnd.3 cells, melatonin activates Akt, which promotes cell survival, and attenuates phosphorylation of JNK, which triggers apoptosis. Thus, melatonin protects bEnd.3 cells against OGD/R-induced injury.
\end{abstract}

\section{Introduction}

Stroke is the third most frequent worldwide cause of adult death $[1,2]$. Specifically, about $80 \%$ of all strokes are ischemic, resulting from arterial occlusion in the brain [1]. Reperfusion after occlusion results in serious brain injury, due to overproduction of reactive oxygen species (ROS), calcium overload [3,4], and blood-brain barrier (BBB) injury [5]. Finally, in ischemic stroke, the brain is damaged because of hypoxia and oxidative stress [6-10]. Reactive oxygen species (ROS) play a key role in the pathogenesis of many diseases, including central nervous system (CNS) diseases [11-14]. During ischemic stroke, the excessive generation of ROS leads to inflammation and cell apoptosis [15-21] and induces mitogen-activated protein kinase (MAPK) signaling [2224]. c-Jun N-terminal kinase (JNK), one of the MAPKs, is activated by a variety of cell stresses, including hyperosmotic shock, hypoxia, and ROS $[25,26]$. JNK plays key roles in apoptosis and inflammation $[27,28]$. JNK signaling is activated by inflammatory cytokines and promotes neuronal cell death [29]. Endothelial cells are also damaged by activation of JNK signaling, in response to oxidative stress [30]. Several studies have demonstrated that, in hypoxia and a state of reoxygenation, cells induce apoptotic signaling through JNK and p38 MAPK [31, 32]. The BBB controls the exchange of materials between blood and the brain and plays an important role in the homeostatic regulation of the brain microenvironment [33]. The tight junctions between capillary endothelial cells, which form an essential structural component of the BBB [34], include membrane proteins like occludin [35] and claudins [36, 37]. Several studies have suggested that hypoxia causes alterations of the tight junction proteins Claudin 5, occludin, ZO-1, and ZO-2, which affect BBB permeability $[38,39]$. In addition, vascular endothelial growth factor (VEGF) is an inducer of vascular leakage [40] and is also known as vascular permeability enhancing factor 
[41, 42]. During ischemia, VEGF interacts with receptors for VEGF on the ischemic vessels and contributes to disruption of the BBB $[43,44]$. Zhang el al. demonstrated that inhibition of VEGF reduces BBB permeability [43]. Melatonin is synthesized in the pineal gland and has been known to function as an antioxidant [45]. Melatonin reduces the cellular toxicity of ROS in ischemia and reperfusion (I/R) brain injury [46]. In an in vivo cerebral ischemia model, several researches have demonstrated that melatonin treatment reduces brain damage in the setting of ischemia or hypoxia-induced injury $[47,48]$. In vitro, melatonin protects primary neuronal cells from apoptotic death [49] and enhances survival of human neuroblastoma cells [50] in the setting of oxygenglucose deprivation- (OGD-) induced injury. Furthermore, melatonin suppresses VEGF expression in cancer cells [51, 52] and inhibits serum VEGF levels in patients [53]. In the present study, we investigate whether melatonin protects brain endothelial cells against oxygen-glucose deprivation followed by reperfusion- (OGD/R-) induced injury. We show that melatonin reduces the generation of ROS, prevents disruption of the $\mathrm{BBB}$ by stabilizing expression of tight junction proteins and suppressing VEGF expression, and attenuates phosphorylation of JNK, a mediator of cellular apoptosis. Therefore, our results suggest that melatonin is important in protecting the BBB against cerebral ischemic damage.

\section{Materials and Methods}

2.1. Cell Culture. Murine brain endothelial cells (bEnd. 3 cells; ATCC, VA, USA) were purchased from ATCC and cultured in Dulbecco's modified Eagle's medium (DMEM, Hyclone Laboratories, UT, USA), supplemented with $10 \%(\mathrm{v} / \mathrm{v})$ fetal bovine serum (FBS, Hyclone Laboratories, UT, USA) and 100 units/mL of penicillin/streptomycin (Hyclone Laboratories, UT, USA), at $37^{\circ} \mathrm{C}$ in a humidified atmosphere in the presence of $5 \% \mathrm{CO}_{2}$ [54]. bEND. 3 cells were used at 13 passages in this study.

2.2. Oxygen-Glucose Deprivation (OGD) and Reperfusion. Confluent cells were transferred to an anaerobic chamber (Forma Scientific, OH, USA) $\left(\mathrm{O}_{2}\right.$ tension, $\left.0.1 \%\right)$ and washed three times with PBS. Then, culture medium was replaced with deoxygenated, glucose-free balanced salt solution, and cells were incubated for $6 \mathrm{~h}$. Following oxygen-glucose deprivation (OGD) injury, cells were incubated for $18 \mathrm{~h}$ under normal growth conditions, with or without drug treatment [55].

2.3. Drug Treatment. Melatonin was purchased from Sigma (Sigma, MO, USA) and dissolved in ethanol. An equivalent volume of ethanol (final: $0.01 \%$ ) or water was added to control and all melatonin-containing wells. bEnd. 3 cells were exposed to $1-100 \mathrm{nM}$ melatonin for $24 \mathrm{~h}$ before OGD/R injury. The present study consisted of four groups: (1) normal control (NC), bEnd.3 cells cultured with normal media without OGD injury; (2) experimental control (EC), bEnd.3 cells cultured in nontreated medium for $18 \mathrm{~h}$ after $6 \mathrm{~h}$ of OGD injury; (3) $10 \mathrm{nM}$ melatonin (Mel $10 \mathrm{nM}$ ), bEnd.3 cells treated with $10 \mathrm{nM}$ melatonin for $24 \mathrm{~h}$ before $6 \mathrm{~h}$ of OGD injury; these cells were then cultured in nontreated medium for $18 \mathrm{~h}$; (4) $100 \mathrm{nM}$ melatonin (Mel $100 \mathrm{nM}$ ): bEnd.3 cells were also treated with $100 \mathrm{nM}$ melatonin (100 $\mathrm{nM}$ melatonin group) for $24 \mathrm{~h}$ before $6 \mathrm{~h}$ of OGD injury. These cells were then cultured in nontreated medium for $18 \mathrm{~h}$. In Akt inhibitor groups, we treated $100 \mathrm{nM}$ Akt inhibitor (Sigma, MO, USA) together with melatonin.

2.4. Hoechst 33258 and Propidium Iodide (PI) Staining. Cell viability was evaluated by staining bEnd. 3 cells with Hoechst 33258 dye (Sigma, MO, USA) and propidium iodide (PI; Sigma, MO, USA). Hoechst dye was added to the culture medium $(2-3 \mu \mathrm{g} / \mathrm{mL})$ and samples were then incubated at $37.8^{\circ} \mathrm{C}$ for $30 \mathrm{~min}$. PI solution was then added $(2-5 \mu \mathrm{g} / \mathrm{mL})$ just before cells were observed with a microscope (BX51; Olympus) equipped with epifluorescence and a UV filter block. PI-positive cells were counted as dead cells [56].

2.5. Cell Viability Assay. bEnd. 3 cells $\left(2 \times 10^{5}\right.$ cells $\left./ \mathrm{mL}\right)$ were seeded in 98-well plates to monitor all experiment conditions, including pretreatment, OGD injury, and reperfusion. Next, cells were rinsed twice with phosphate-buffered saline (PBS), and culture medium was replaced with serumfree medium and $100 \mu \mathrm{L}$ 3-[4,5-dimethylthiazol-2-yl]-2,5diphenyl tetrasodium bromide (MTT) (Sigma, MO, USA) solution $(5 \mathrm{mg} / \mathrm{mL}$ in PBS) per well. After $1 \mathrm{~h}$ of incubation, medium was removed and dimethyl sulfoxide (DMSO) was added to solubilize the purple formazan product of MTT treatment. The supernatant from each well was analyzed using an ELISA plate reader (Labsystems Multiskan MCC/340; Fisher Scientific, PA, USA) at a wavelength of $570 \mathrm{~nm}$, with background subtraction at $650 \mathrm{~nm}$. All experiments were repeated at least three times. Cell viability in the control medium, without any treatment, was represented as $100 \%$. Cell viability was reported as a relative value, compared to the control group.

2.6. Lactate Dehydrogenase ( $\mathrm{LDH}$ ) Assay. Cytotoxicity in all treatment groups was quantified by measuring the amount of $\mathrm{LDH}$ released into the culture medium from OGD/R-injured cells $[57,58]$. LDH release (cytotoxicity \%) was calculated by dividing the value at the experimental time point by the maximum value. The maximum $\mathrm{LDH}$ release was measured after freezing each culture at $-70^{\circ} \mathrm{C}$ overnight, followed by rapid thawing, which induced nearly complete cell damage.

2.7. Determination of Intracellular ROS. The level of intracellular ROS in each treatment group was measured using a fluorescent probe, $2^{\prime}, 7^{\prime}$-dichlorodihydrofluorescein diacetate (DCF-DA; Invitrogen, CA, USA), as previously described [59]. Cells were plated at a density of $1 \times 10^{6}$ cells $/ \mathrm{mL}$ and treated with melatonin for $24 \mathrm{~h}$. After melatonin pretreatment, OGD injury and reperfusion were conducted. Then, bEND. 3 cells were treated with $5 \mu \mathrm{M}$ DCF-DA for $30 \mathrm{~min}$ at $37^{\circ} \mathrm{C}$. After washing with $\mathrm{PBS}$, fluorescence was measured 
with a microscope (Nikon TS100-F ECLIPSE) equipped with a CCD camera (Hamamatsu Photonics) [54].

2.8. Western Blot Analysis. After pretreatment, OGD injury, and restoration, cells were washed rapidly with ice-cold PBS, scraped, and collected. Cell pellets were lysed with ice-cold RIPA buffer (Sigma, MO, USA). The lysates were centrifuged at $13,200 \mathrm{rpm}$ for $1 \mathrm{~h}$ at $4^{\circ} \mathrm{C}$ to produce wholecell extracts. Protein content was quantified using the BCA method (Pierce, IL, USA). Protein $(20 \mu \mathrm{g})$ was separated on a $10 \%$ SDS-polyacrylamide (PAGE) gel and transferred onto a polyvinylidene difluoride (PVDF) membrane. After blocking with $5 \%$ bovine serum albumin, prepared in Trisbuffered saline/Tween (TBS-T; $20 \mathrm{nM}$ Tris (pH 7.2); $150 \mathrm{mM}$ $\mathrm{NaCl} ; 0.1 \%$ Tween 20), for $1 \mathrm{~h}$ at $\mathrm{RT}$, immunoblots were incubated overnight at $4^{\circ} \mathrm{C}$ with primary antibodies that specifically detect Akt ( $1: 2000$, Cell Signaling, MA, USA), pAkt (1:2000, Cell Signaling, MA, USA), JNK $(1: 2000$, Cell Signaling, MA, USA), p-JNK (1:2000, Cell Signaling, MA, USA), Claudin 5 ( $1: 1000$, Santa Cruz, CA, USA), VEGF (1:1000, Millipore, MA, USA), Bax $(1: 2000$, Cell Signaling, MA, USA), or $\beta$-actin $(1: 2000$, Cell Signaling, MA, USA). Next, blots were incubated with HRP-linked anti-mouse and -rabbit IgG antibodies purchased from Abcam (Cambridge, MA, USA) for $1 \mathrm{~h}$ at RT. Enhanced chemiluminescence was performed by ECL (Pierce, IL, USA) [54].

2.9. Immunocytochemistry (ICC). The expression of VEGF and Claudin 5 in bEnd. 3 cells was confirmed by immunocytochemistry. Cells in all experimental groups were washed three times with PBS, fixed with $4 \%$ paraformaldehyde for $3 \mathrm{~h}$, and then washed with PBS. bEnd. 3 cells were permeabilized with $0.025 \%$ Triton X-100 and blocked for $1 \mathrm{~h}$ at RT with dilution buffer (Invitrogen, CA, USA). Primary anti-rabbit VEGF (1:500, Millipore, MA, USA) and antirabbit Claudin 5 (1:500, Santa Cruz, CA, USA) antibodies were prepared in dilution buffer, added to samples, and incubated for $3 \mathrm{~h}$ at RT. Primary antibody was then removed and cells were washed three times for 3 min each with PBS. Later, samples were incubated with FITC-conjugated goat, anti-rabbit $(1: 200$, Jackson Immunoresearch, PA, USA) or Rhodamine-conjugated donkey, or anti-rabbit secondary antibodies (1:500, Millipore, MA, USA) for $2 \mathrm{~h}$ at RT. Cells were washed again three times for 3 min each with PBS and stained with $1 \mu \mathrm{g} / \mathrm{mL} 4^{\prime}, 6$-diamidino-2-phenylindole (DAPI) $(1: 100$, Invitrogen, CA, USA) for $10 \mathrm{~min}$ at RT. Fixed samples were imaged using a Zeiss LSM 700 confocal microscope (Carl Zeiss, NY, USA).

2.10. Statistical Analysis. Statistical comparisons were performed using independent $t$-tests for two groups. SPSS software was used for all analyses. Data were expressed as mean \pm S.E.M. of three independent experiments. Differences were considered significant at ${ }^{\#} P<0.1,{ }^{*} P<0.05$, and ${ }^{* *} P<0.001$.

\section{Results}

3.1. Melatonin Attenuates the Cell Death of bEND.3 Cells after $O G D / R$-Induced Injury. To confirm the protective effect of melatonin on OGD/R-induced injury, we first conducted an MTT assay to check cell viability in all treatment groups (Figure 1(a)). Cell viability showed that the OGD/R injury exposed group exhibited decreased cell viability, compared to the normal control group (100\% cell viability in the normal control group; $39 \%$ cell viability in the OGD/R injury exposed group). We checked the cell viability by pretreatment with melatonin $1 \mathrm{nM}$ to $100 \mathrm{nM}$. Cell viability in $1 \mathrm{nM}$ and $5 \mathrm{nM}$ melatonin pretreatment group was almost not different from the OGD/R injury exposed group. Treatment with $10 \mathrm{nM}$ melatonin also did not change cell viability compared to the OGD/R injury exposed group ( $48 \%$ cell viability in the Mel $10 \mathrm{nM}$ group). However, treatment with $100 \mathrm{nM}$ melatonin obviously increased cell viability after OGD/Rinduced injury, compared to the normal control group (62\% cell viability in the Mel $100 \mathrm{nM}$ group) (Figure 1(a)). In addition, we evaluated cytotoxicity in bEND. 3 cells following OGD/R injury using an LDH assay (Figure 1(b)). Cytotoxicity was $12 \%$ in the normal control group but was $28 \%$ in the OGD/R injury exposed group. Cytotoxicity in $1 \mathrm{nM}$ and $5 \mathrm{nM}$ melatonin pretreatment group was not largely different from the OGD/R injury exposed group. Treating cells with $10 \mathrm{nM}$ melatonin resulted in $21 \%$ cytotoxicity and treating cells with $100 \mathrm{nM}$ melatonin resulted in 18\% cytotoxicity (Figure 1(b)). Considering cell viability and cytotoxicity data, we decided two concentrations of melatonin (10 $\mathrm{nM}$ melatonin concentration (among the low concentrations: $1 \mathrm{nM}, 5 \mathrm{nM}$, and $10 \mathrm{nM}$ ) and $100 \mathrm{nM}$ melatonin concentration (among the high concentrations: $50 \mathrm{nM}, 100 \mathrm{nM}$ )) to compare the effect of melatonin easily. We also conducted Hoechst/PI staining to check the dead cells in all groups (Figure 1(c)). Hoechst/PI staining images showed that only melatonin treatment groups were almost not different from the normal control group. PI-positive cells (dead cells) evidently were increased in the OGD/R injury exposed group, compared to the normal control group. $10 \mathrm{nM}$ and $100 \mathrm{nM}$ melatonin treatment promoted cell survival and inhibited cell death against OGD/Rinduced injury. In the $100 \mathrm{nM}$ melatonin treatment group, the protective effect of melatonin against $\mathrm{OGD} / \mathrm{R}$ injury death in bEND. 3 cells was more obvious than in the $10 \mathrm{nM}$ melatonin treatment group (Figure 1(c)). Taken together, these findings suggest that melatonin attenuates OGD/R-induced damage in brain endothelial cells.

\subsection{Melatonin Decreases OGD/R-Induced ROS Production.} We measured ROS levels using DCF-DA reagent, a fluorescent dye that visualizes ROS. DCF-DA-positive cells increased after OGD/R. ROS levels in melatonin pretreatment groups (10 nM, $100 \mathrm{nM}$ melatonin) were not largely different from ROS levels in the normal control group. In the OGD/R injury exposed group, ROS levels were evidently increased compared to the normal control group. This was partially blocked by pretreatment with $10 \mathrm{nM}$ melatonin (Figures 2(a) and 2(b)). $100 \mathrm{nM}$ melatonin pretreatment clearly decreased the number of DCF-DA-positive cells, compared 


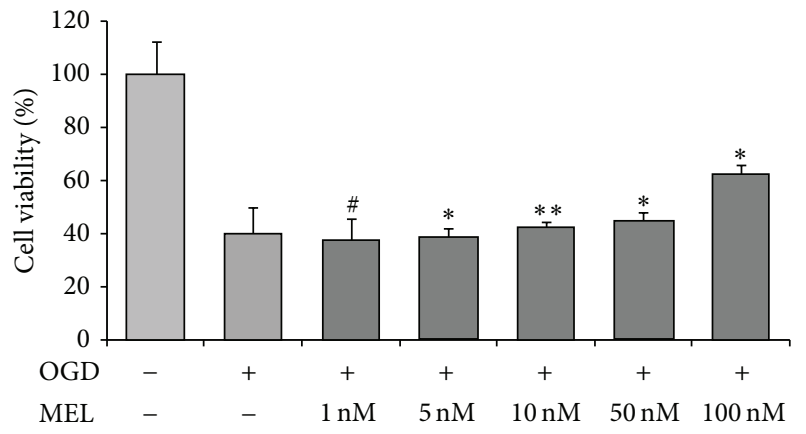

(a)
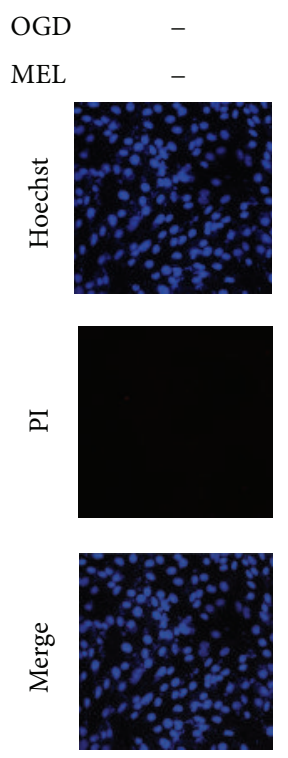

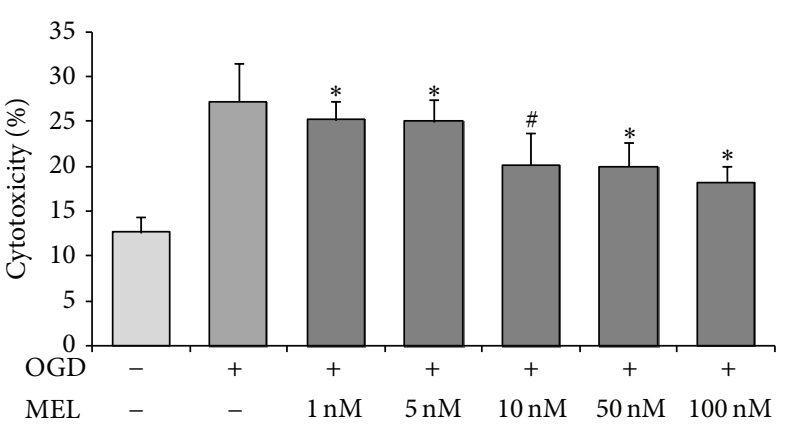

(b)

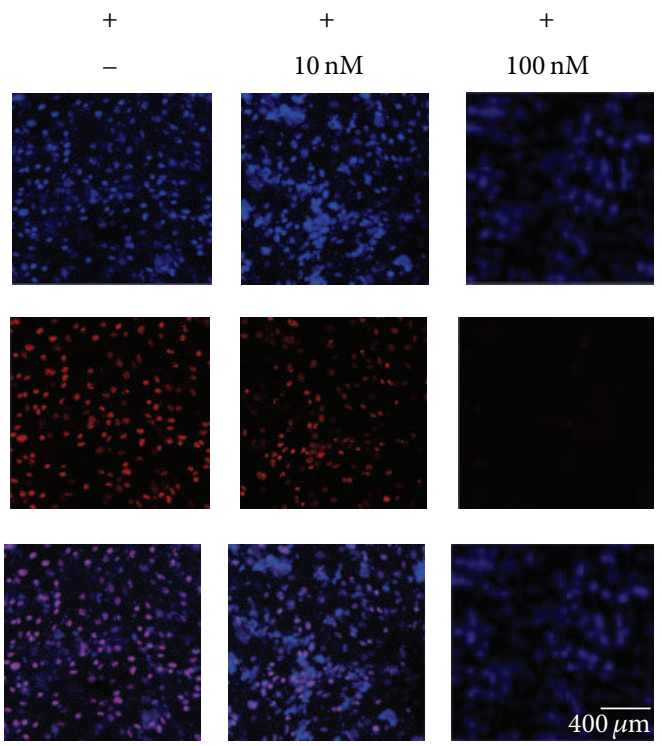

(c)

FIGURE 1: The measurement of brain endothelial cell viability after OGD/R-induced injury. (a) A 3-(4,5-dimethylthiazol-2-yl)-2,5diphenyltetrazolium bromide (MTT) assay shows that bEND.3 cells in the OGD/R injury exposed group exhibited decreased viability compared to cells in the normal control group. Cell viability of bEND. 3 cells in $1 \mathrm{nM}$ and $5 \mathrm{nM}$ melatonin pretreatment groups was not largely different form OGD/R injury exposed group. bEND.3 cells in $10 \mathrm{nM}, 50 \mathrm{nM}$, and especially $100 \mathrm{nM}$ melatonin pretreatment groups exhibited increased cell viability compared to OGD/R injury exposed group. Data are expressed as mean \pm S.E.M. $\left({ }^{\#} P<0.1\right.$, ${ }^{*} P<0.05$, and $\left.{ }^{* *} P<0.001\right)$. (b) Cytotoxicity (\%) was measured using an LDH assay. Cytotoxicity increased in OGD/R injury exposed group compared to the normal control group. Melatonin treatment (especially $100 \mathrm{nM}$ melatonin pretreatment) reduced cytotoxicity after OGD/R injury. Data are expressed as mean \pm S.E.M. $\left({ }^{\#} P<0.1,{ }^{*} P<0.05\right.$, and $\left.{ }^{* *} P<0.001\right)$. (c) Dead and live cells were measured by Hoechst/PI staining. PI-positive cells (red) are regarded as the dead cells. PI-positive cells were higher in OGD/R injury exposed group than in the normal control group. Melatonin treatment groups (both in $10 \mathrm{nM}$ and in $100 \mathrm{nM}$ melatonin groups) exhibited reduced PI-positive cells compared to the OGD/R injury exposed group. Hoechst: Hoechst 33342 (blue color) and PI: propidium iodide (red color). Scale bar $=400 \mu \mathrm{m}$.

to the OGD/R injury exposed group. This result suggests that melatonin inhibits OGD/R-induced ROS production in brain endothelial cells.

\subsection{Melatonin Prevents Degradation of Tight Junction Proteins} against $O G D / R$ Injury. To check the protective effect of melatonin on the integrity of tight junctions during $O G D / R$, we measured the level of Claudin 5, a tight junction protein, by immunocytochemistry (Figure 3(a)) and western blot analysis (Figure 3(b)). OGD/R stress obviously decreased the expression of Claudin 5 in the bEND. 3 cells compared to the normal control (NC) group. The expression of Claudin
5 did not nearly change in the $10 \mathrm{nM}$ melatonin treatment group, compared to the experimental control (EC) group which in exposed OGD/R injury. The expression of Claudin 5 was evidently attenuated by treatment with $100 \mathrm{nM}$ melatonin (Figures 3(a) and 3(b)). This result shows that melatonin pretreatment protects degradation of Claudin 5 following OGD/R injury. Namely, melatonin may prevent deterioration of tight junctions in response to OGD/R-induced injury.

3.4. Melatonin Attenuates the Expression of VEGF after OGD/R-Induced Injury. We conducted immunocytochemistry (Figures 4(a) and 4(b)) and western blot analysis 


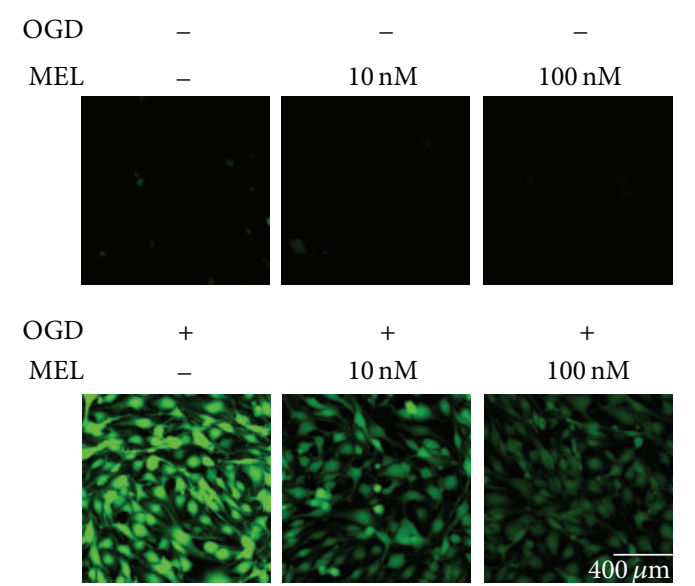

(a)

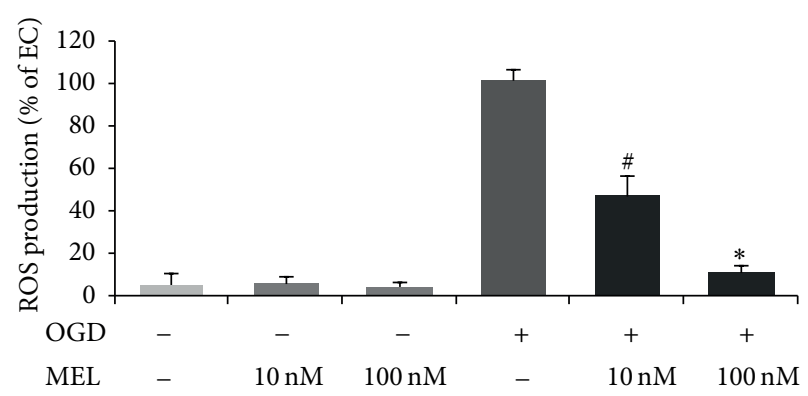

(b)

FIGURE 2: Immunocytochemistry to measure ROS generation in bEND.3 cells after OGD/R-induced injury. bEND. 3 cells were treated with melatonin for $24 \mathrm{~h}$ before OGD/R injury. ROS levels were measured using DCF-DA. (a) ROS levels in only melatonin treatment groups (both $10 \mathrm{nM}$ and $100 \mathrm{nM}$ melatonin pretreatment groups) were the same as the normal control group. ROS levels in bEND.3 cells were increased in OGD/R injury exposed group. Under OGD/R injury, ROS levels in the melatonin pretreatment group were decreased compared to OGD/R injury exposed group. Melatonin decreased the OGD/R-induced increase in DCF-DA-positive cells (green). (b) ROS production was calculated by measuring the intensity of ROS. This graph shows relative intensity as a percentage of OGD/R injury exposed group. Data are expressed as mean \pm S.E.M. $\left({ }^{\#} P<0.1\right.$ and $\left.{ }^{*} P<0.05\right) .2^{\prime}, 7^{\prime}$-Dichlorodihydrofluorescein diacetate (DCF-DA): green. Scale bar $=400 \mu \mathrm{m}$.

(Figure 4(c)) to confirm the expression of VEGF in all treatment groups. This result indicated that the expression of VEGF became considerably elevated after OGD/R injury in the bEND.3 cells. However, the expression of VEGF was reduced by melatonin treatment (both $10 \mathrm{nM}$ and $100 \mathrm{nM}$ melatonin pretreatment) (Figures 4(a) and 4(b)). This finding suggests that melatonin attenuates the expression of VEGF in brain endothelial cells following OGD/R-induced injury.

3.5. Melatonin Protects bEND.3 Cells via Akt Activation and JNK Suppression. To investigate whether Akt signaling was activated in OGD/R-induced stress, we first measured the phosphorylation status of Akt by western blot analysis (Figure 5(a)). Phosphorylation of Akt is associated with activation of Akt signaling and cell survival. Our result suggests that the protein expression of phosphor-Akt/Akt in the EC group is attenuated compared to the NC group. Expression of phosphor-Akt in the $10 \mathrm{nM}$ melatonin treatment group did not nearly change compared to the EC group. However, expression of phosphor-Akt in the $100 \mathrm{nM}$ melatonin treatment group was higher than in the EC group (Figure 5(a)). Next, we also examined the phosphorylation status of JNK by western blot analysis (Figure 5(b)), because the phosphorylation of JNK correlates with activation of apoptosis signaling. The expression of phosphor-JNK was decreased by melatonin treatment after OGD/R-induced injury. Pretreatment with $100 \mathrm{nM}$ melatonin resulted in the obvious inhibition of JNK signaling whereas JNK activation in $10 \mathrm{nM}$ melatonin pretreatment group was not largely different from the EC group (Figure 5(b)). These results suggest that melatonin $100 \mathrm{nM}$ increases Akt activation and suppresses JNK activation. To confirm the relationship between melatonin and Akt signaling, we checked the expression of Bax by western blot analysis (Figure 5(c)). We confirmed that the protein expression of Bax in the bEND. 3 cells was increased under OGD/R injury compared to the NC group. Also, $10 \mathrm{nM}$ and $100 \mathrm{nM}$ melatonin treatment reduced the protein expression of Bax under OGD/R injury. When we checked the expression of Bax in OGD/R injured bEND.3 cells with Akt inhibitor and melatonin pretreatment, we confirmed that Akt inhibitor pretreatment did not reduce the expression of Bax in melatonin pretreatment groups (Figure 5(d)). These findings indicate that melatonin may promote Akt signaling and suppress JNK signaling. Specifically, melatonin may attenuate the expression of Bax, known as an apoptotic protein through Akt activation in brain endothelial cells following OGD/R stress.

\section{Discussion}

Ischemic stroke causes oxidative stress in the brain as well as various neuropathological impairments [60]. BBB disruption is commonly observed in stroke patients [61, 62]. BBB damage is aggravated by reperfusion after ischemia [63]. ROS are generated during cerebral ischemia-reperfusion injury and lead to severe brain damage by promoting the cell apoptosis pathway $[64,65]$. Also, ROS cause BBB hyperpermeability, brain edema, hemorrhage, and inflammation [66]. In the present study, we induced OGD/R injury, which is known as an appropriate in vitro model of stroke $[67,68]$, in brain endothelial cells to investigate the effect of ischemiareperfusion injury. Recent research suggests that antioxidants attenuate oxidative damage induced by ischemia-reperfusion injury by decreasing mechanisms of ROS production [69]. Previous researches have suggested that antioxidants preserve $\mathrm{BBB}$ disruption and attenuate ROS generation after cerebral 

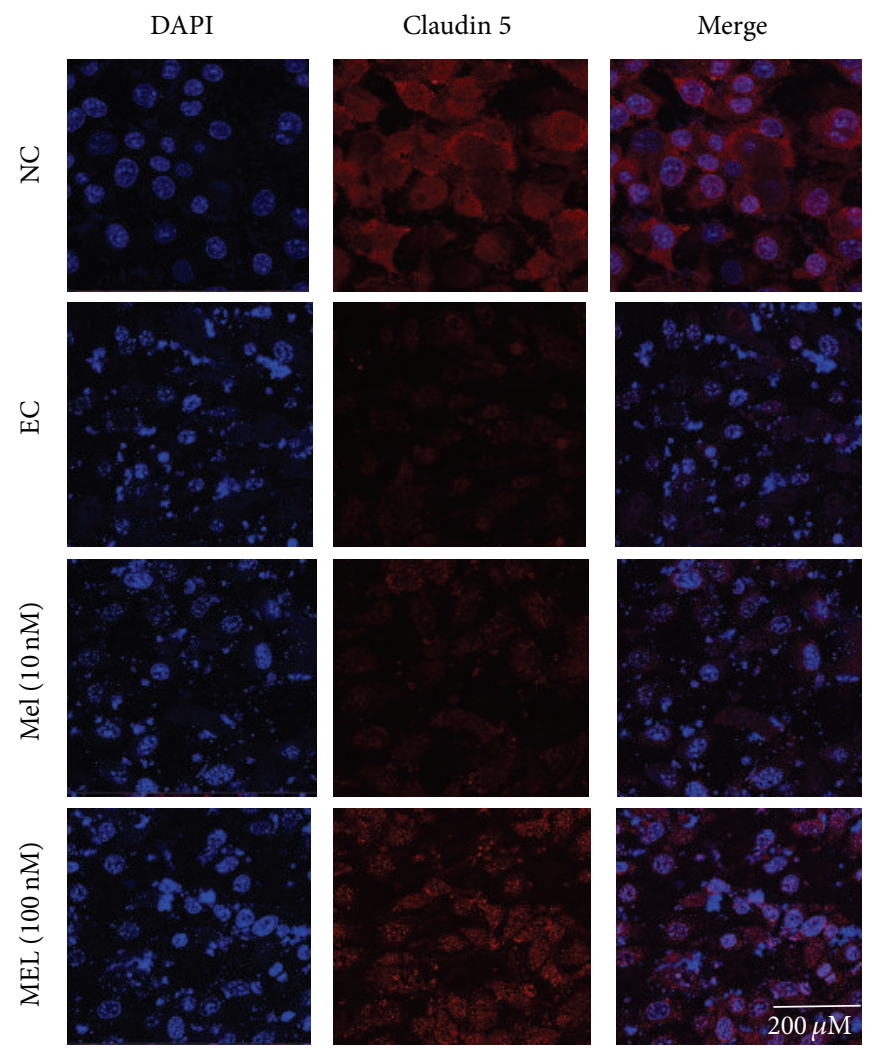

(a)

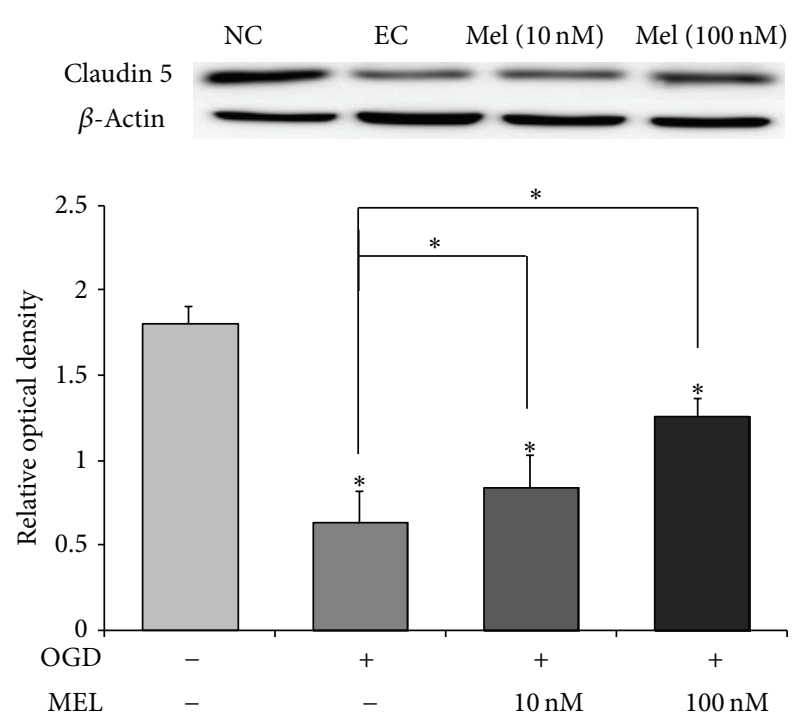

(b)

FIGURE 3: The measurement of the tight junction protein in bEND.3 cells after OGD/R-induced injury. (a) The level of Claudin 5, a tight junction protein, was evaluated by immunocytochemistry. This image shows that expression of Claudin 5 in the experimental control (EC) group decreased compared to the normal control (NC) group. Melatonin increased the expression of Claudin 5 under OGD/R injury (green). In the $\mathrm{Mel}(10 \mathrm{nM})$ and $\mathrm{Mel}(100 \mathrm{nM})$ groups, the expression of Claudin 5 was higher than in the EC group. Claudin 5 was preserved in the melatonin treatment group, following OGD/R-induced injury. Scale bar: $200 \mu \mathrm{m}$, Claudin 5: red, and 4',6-diamidino-2-phenylindole (DAPI): blue. (b) Western blotting showed that the relative protein level of Claudin 5 was reduced in EC compared to the NC group. The relative level of Claudin 5 was increased in $\mathrm{Mel}(10 \mathrm{nM})$ and $\mathrm{Mel}(100 \mathrm{nM})$ groups, compared to the EC group. The bar graph shows the quantification of Claudin 5 protein in all groups. $\beta$-Actin was used as an internal control. Data are expressed as mean \pm S.E.M. $\left({ }^{*} P<0.05\right)$. (i) Normal control (NC): bEnd.3 cells cultured with normal media without OGD injury, (ii) experimental control (EC): bEnd.3 cells cultured in nontreated medium for $18 \mathrm{~h}$ after $6 \mathrm{~h}$ of OGD injury, and (iii) $10 \mathrm{nM}$ melatonin (Mel $10 \mathrm{nM}$ ): bEnd. 3 cells treated with $10 \mathrm{nM}$ melatonin for $24 \mathrm{~h}$ before $6 \mathrm{~h}$ of OGD injury. These cells were then cultured in nontreated medium for $18 \mathrm{hr}$. (iv) $100 \mathrm{nM}$ melatonin (Mel $100 \mathrm{nM}$ ): bEnd. 3 cells were also treated with $100 \mathrm{nM}$ melatonin (100 nM melatonin group) for $24 \mathrm{~h}$ before $6 \mathrm{~h}$ of OGD injury. These cells were then cultured in nontreated medium for $18 \mathrm{~h}$. 

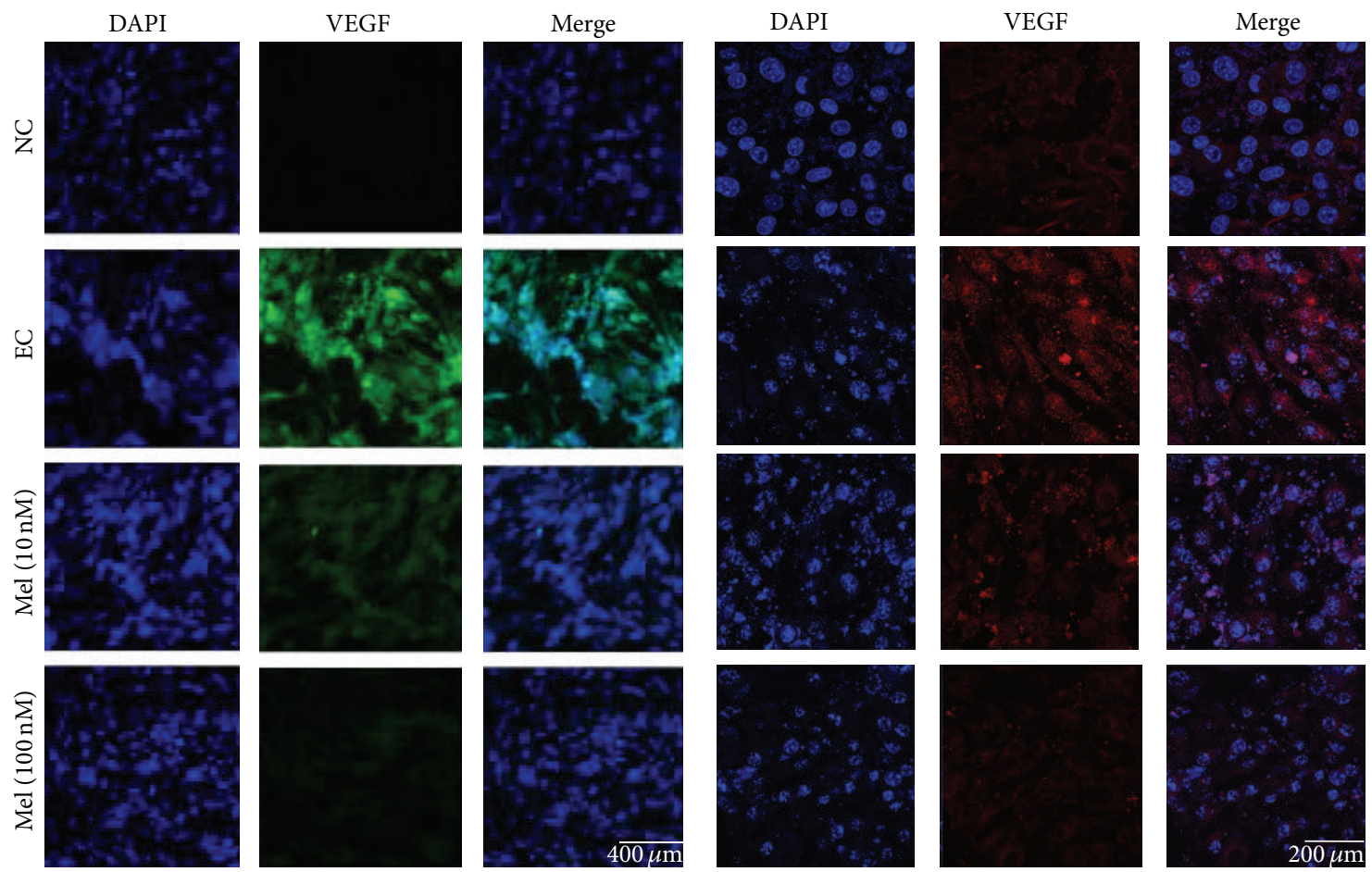

(a)

(b)
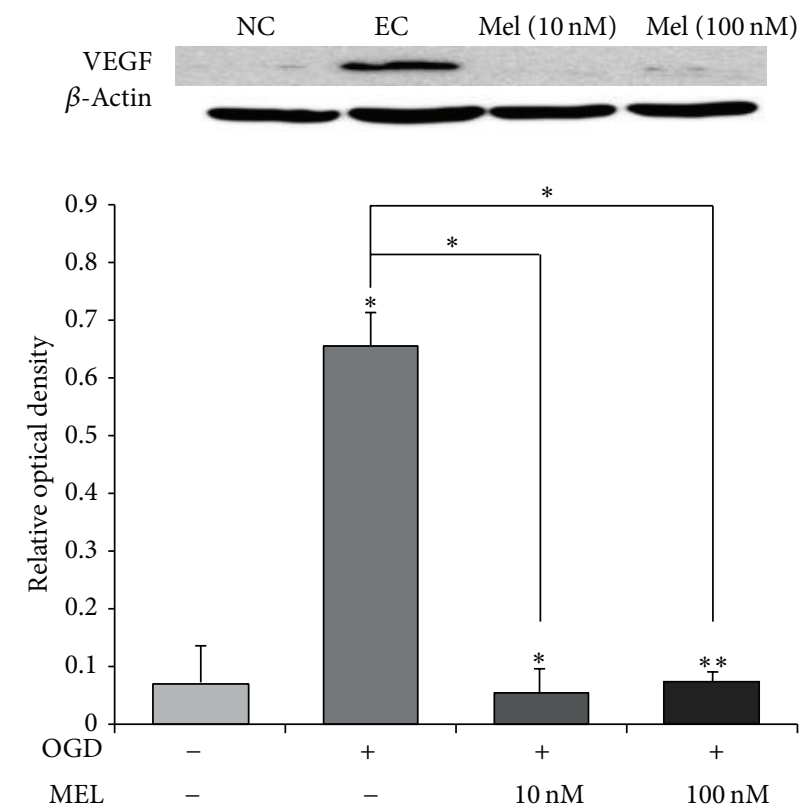

(c)

FIGURE 4: The measurement of VEGF expression in bEND.3 cells after OGD/R-induced injury. (a) The level of VEGF was evaluated by immunocytochemistry. This image shows that the expression of VEGF in the experimental control (EC) group was increased compared to the normal control (NC) group. Melatonin attenuated the OGD/R-induced increase in the number of VEGF-positive cells. In Mel (10 nM) and Mel $(100 \mathrm{nM})$ groups, the expression of VEGF was lower than in the EC group. VEGF expression was attenuated in the melatonin treatment group under OGD/R-induced injury. Scale bar: $400 \mu \mathrm{m}$. (b) Scale bar: $200 \mu \mathrm{m}$, vascular endothelial growth factor (VEGF): green, red, and $4^{\prime}$,6-diamidino-2-phenylindole (DAPI): blue. (c) Western blotting showed that the protein level of VEGF was evidently increased in EC compared to the NC group. The protein level of VEGF was attenuated in both Mel $(10 \mathrm{nM})$ and Mel (100 nM) groups, compared to the EC group. The bar graph shows the quantification of VEGF protein in all groups. $\beta$-Actin was used as an internal control. Data are expressed as mean \pm S.E.M. $\left({ }^{*} P<0.05\right.$ and $\left.{ }^{* *} P<0.001\right)$. 


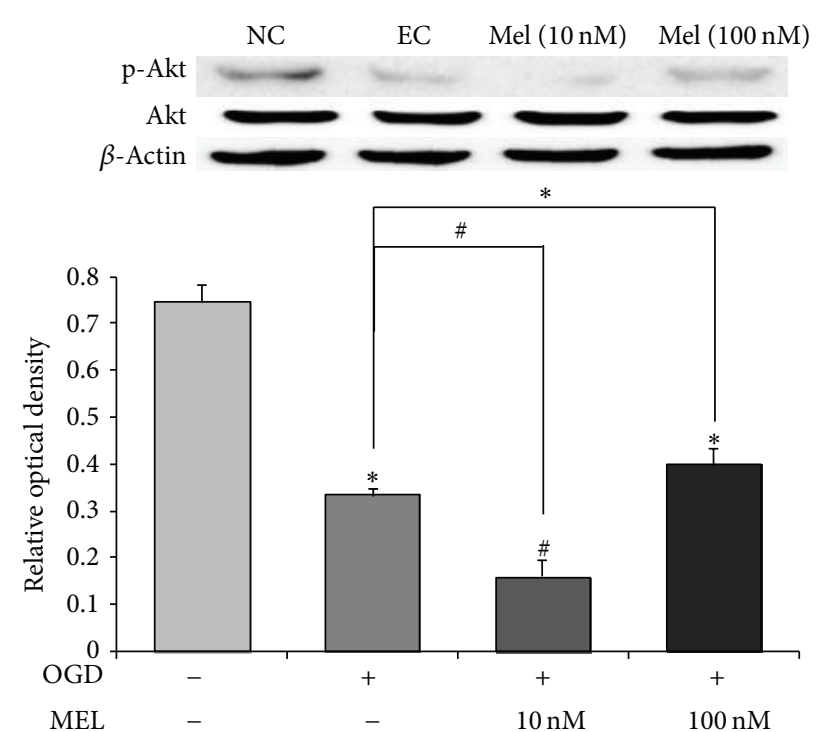

(a)

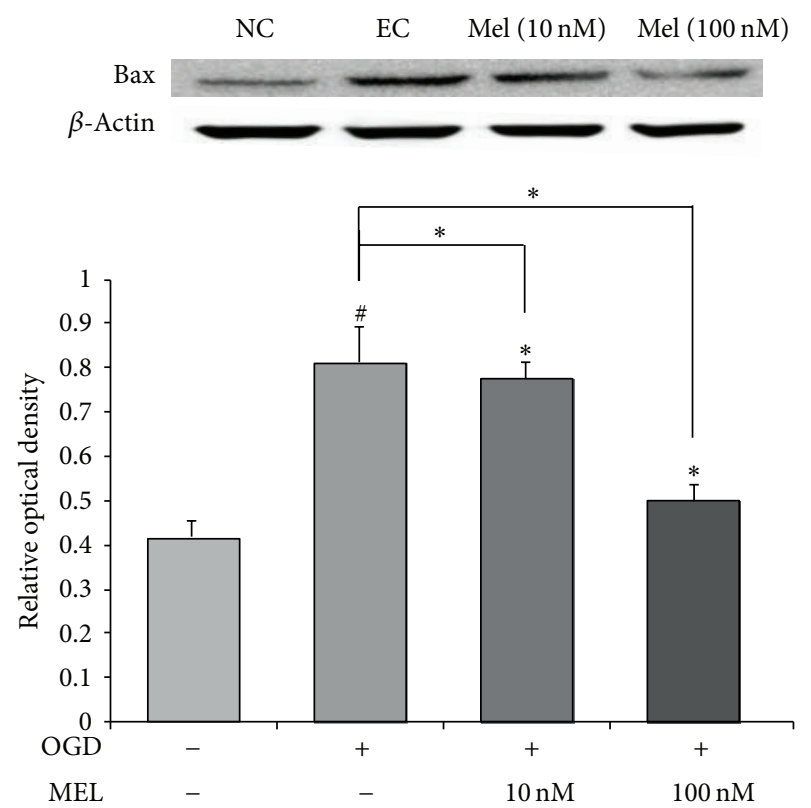

(c)

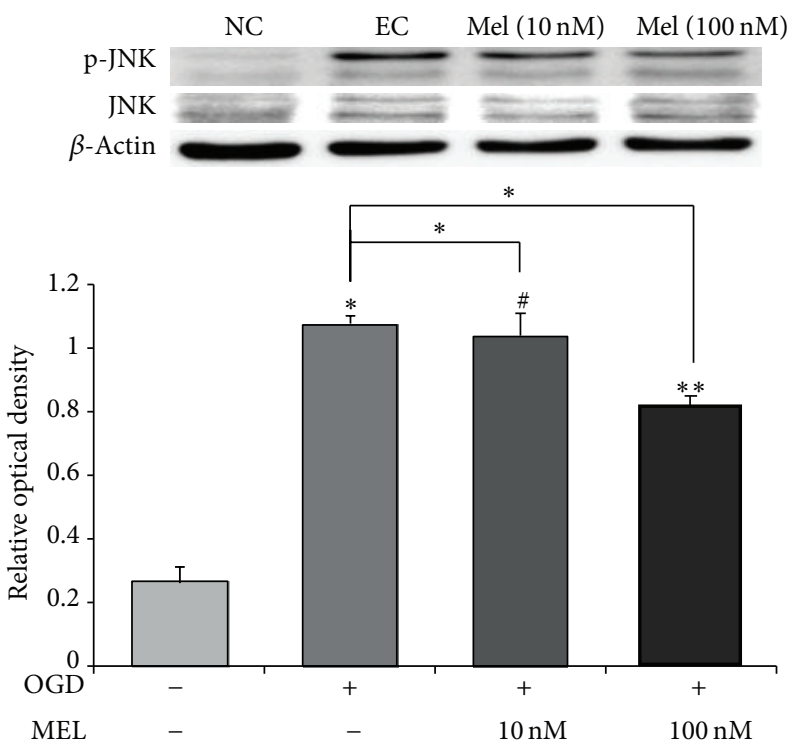

(b)

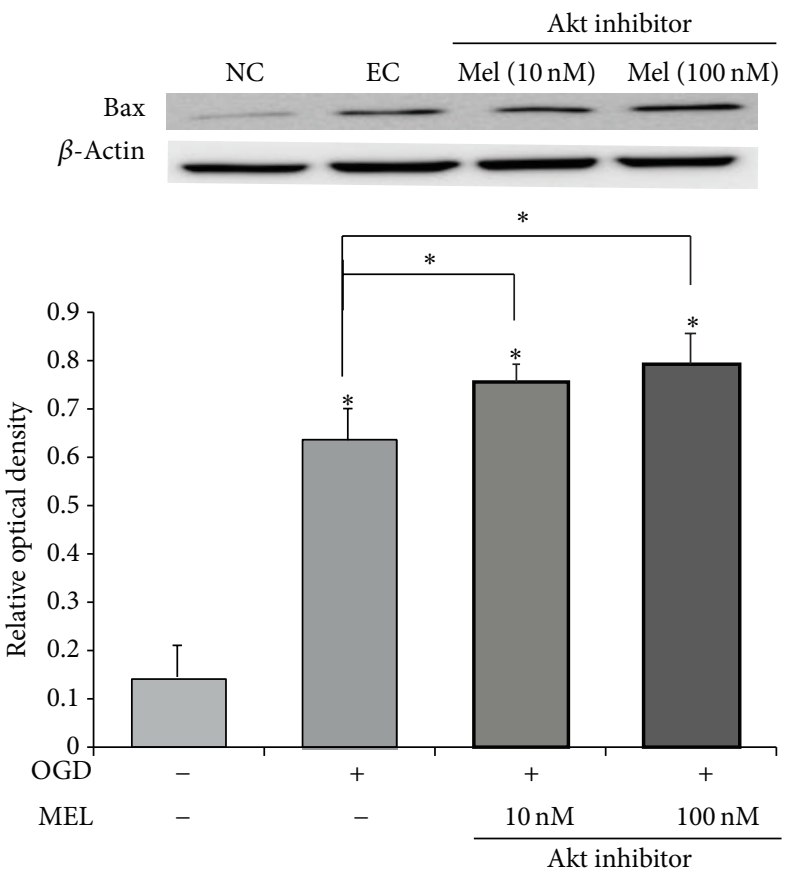

(d)

FIGURE 5: The measurement of JNK, Akt, and Bax expression in brain endothelial cells after OGD/R-induced injury. (a) Western blotting showed that the relative protein level of phosphor-Akt was reduced in EC compared to the NC group. The protein level of phosphor-Akt was increased in Mel (100 nM) groups, compared to the EC group. The bar graph shows the quantification of phosphor-Akt/Akt protein in all groups. (b) Western blotting showed that the relative protein expression of phosphor-JNK increased in the EC group, compared to the NC group. The relative level of phosphor-JNK decreased in Mel $10 \mathrm{nM}$ and Mel $100 \mathrm{nM}$ groups, compared to the EC group. The bar graph shows the quantification of phosphor-JNK/JNK protein in all groups. (c) Western blotting showed that the relative protein expression of Bax increased in the EC group, compared to the NC group. The protein level of Bax decreased in Mel $10 \mathrm{nM}$ and Mel $100 \mathrm{nM}$ groups, compared to the EC group. The bar graph shows the quantification of Bax protein in all groups. (d) Western blotting showed the relative protein expression of Bax by melatonin and $100 \mathrm{nM}$ Akt inhibitor pretreatment under OGD/R injury. The expression of Bax was increased in the EC treatment group, compared to the NC group. The protein level of Bax was increased in Mel $10 \mathrm{nM}$ and Mel $100 \mathrm{nM}$ groups with $100 \mathrm{nM}$ Akt inhibitor copretreatment, compared to the EC group. The bar graph shows the quantification of Bax in all groups. $\beta$-Actin was used as an internal control. Data are expressed as mean \pm S.E.M. $\left({ }^{\#} P<0.1,{ }^{*} P<0.05\right.$, and $\left.{ }^{* *} P<0.001\right)$. Protein kinase B (Akt), phosphorylated Akt (p-Akt), c-Jun N-terminal kinases (JNK), and phosphorylated JNK (p-JNK). 
ischemia reperfusion in vivo [70-72] and in vitro $[73,74]$. Melatonin is known as an antioxidant [75], a powerful free radical scavenger [76-78], and the cellular protector against various oxidative stress-associated diseases $[79,80]$. Several studies in animals have suggested that melatonin reduces cellular damage by decreasing ROS in ischemia-reperfusion injury [46, 81, 82] and ischemia-hypoxia injury [83]. In the present study, we confirmed that melatonin reduces OGD/R-induced ROS generation in brain endothelial cells and prevents cell death of brain endothelial cells following OGD/R injury. Hypoxia causes degradation of tight junction proteins, such as Claudin 3, ZO-1 and ZO-2, and occludin $[38,39]$. Several studies have demonstrated that claudins are major proteins in tight junctions [84-87], which are essential structural components of the BBB [34]. And, Claudin 5 is an important molecule that promotes disruption of the BBB in hypoxic conditions [88]. Tao et al. have demonstrated that melatonin prevents degradation of ZO-1, a tight junction protein that protects against ischemic injury in endothelial cells [89]. To determine the protective effect of melatonin on impaired BBB function caused by ischemia reperfusion, we examined Claudin 5 protein expression in brain endothelial cells following $\mathrm{OGD} / \mathrm{R}$ injury. Our findings suggest that melatonin may prevent BBB disruption during ischemiareperfusion injury by inhibiting degradation of the Claudin 5 tight junction protein. Hypoxia results in increased paracellular permeability [38, 90-92], leading to formation of cerebral edema [93]. Hypoxia induces the expression of VEGF [9497], which is considered as one of the most important factors that stimulates the formation of new blood vessels $[94,95]$. VEGF increases the permeability of blood vessels $[92,98,99]$ and leads to vasogenic edema [100-103]. Several studies have demonstrated that VEGF increases BBB permeability [99], while inhibition of VEGF reduces BBB permeability [43]. Melatonin protects BBB hyperpermeability and reduces brain edema in ischemic stroke [104, 105]. Also, recent research has shown that melatonin reduces expression of VEGF in hypoxic damage [53, 106-108]. In the present study, our results showed that melatonin reduced the expression of VEGF in brain endothelial cells following OGD/R-induced injury. In oxidative stress, ROS acts as an important mediator to activate the MAPK pathway $[23,24]$. The phosphatidylinositol-3kinase/protein kinase B (PI3K/Akt) signaling pathway is considered to be one of the cell survival pathways [109]. Many researches have demonstrated that Akt plays a major role in protection from cell death under oxidative stress [110115] and attenuates ROS production, which protects cells [116]. In brain endothelial cells, Akt enhances cell survival and inhibits apoptosis [117-119]. Melatonin promotes Akt signaling to protect cells in response to stress [120]. In the present study, our result showed that melatonin enhanced Akt activation following OGD/R injury. This finding may indicate that melatonin protects brain endothelial cells via Akt activation in the setting of ischemia-reperfusion injury. In addition, Akt can protect cellular apoptosis by regulating a proapoptotic protein such as Bax [121-124]. Several studies demonstrated that melatonin may regulate the Bax expression and may be involved in the apoptosis signaling [125, 126]. In the present study, our results showed that melatonin may regulate the Bax expression through regulating Akt activation. Considering that $\mathrm{Bax}$ is the proapoptotic protein, melatonin may protect the apoptosis of brain endothelial cells through suppressing the expression of Bax in response to hypoxia and reperfusion stress. JNK signaling contributes to cellular apoptosis triggered by various stresses, including oxidized LDL, proinflammatory cytokines, or high glucose [127-129]. Specifically, excessive ROS generation is closely linked to JNK activation [130-132]. JNK activation triggers the mitochondrial apoptotic pathway $[133,134]$ and disrupts the BBB [135]. Several studies have shown that JNK inhibitors exert protective effects against ischemic injury in a rodent model [136-139]. In the present study, our findings suggest that melatonin attenuates JNK activation in OGD/R-exposed brain endothelial cells. This result indicates that melatonin may inhibit the death of brain endothelial cells via JNK suppression. In conclusion, melatonin protects brain endothelial cells against ischemic-reperfusion injury by reducing the production of ROS, by preserving tight junction proteins, by attenuating expression of VEGF, and by regulating Akt activation and JNK suppression. Hence, this study suggests that melatonin may play as the protector on brain endothelial cells under brain hypoxic injury such as stroke. For application to the patients with stroke, this study has many limitations because of confirmation only in vitro study. However, these findings may provide the basic data for the further study on stroke.

\section{Conflict of Interests}

The authors declare that there is no conflict of interests regarding the publication of this paper.

\section{Acknowledgment}

This research was supported by the Brain Research Program through the National Research Foundation of Korea (NRF), which is funded by the Ministry of Science, ICT \& Future Planning (2012-0005827).

\section{References}

[1] R. W. V. Flynn, R. S. M. MacWalter, and A. S. F. Doney, "The cost of cerebral ischaemia," Neuropharmacology, vol. 55, no. 3, pp. 250-256, 2008.

[2] K. P. Doyle, R. P. Simon, and M. P. Stenzel-Poore, "Mechanisms of ischemic brain damage," Neuropharmacology, vol. 55, no. 3, pp. 310-318, 2008.

[3] S. Kuroda and B. K. Siesjö, "Reperfusion damage following focal ischemia: pathophysiology and therapeutic windows," Clinical Neuroscience, vol. 4, no. 4, pp. 199-212, 1997.

[4] T. Nakamura, H. Minamisawa, Y. Katayama et al., "Increased intracellular $\mathrm{Ca}^{2+}$ concentration in the hippocampal CA1 area during global ischemia and reperfusion in the rat: a possible cause of delayed neuronal death," Neuroscience, vol. 88, no. 1, pp. 57-67, 1999.

[5] N. J. Abbott, A. A. K. Patabendige, D. E. M. Dolman, S. R. Yusof, and D. J. Begley, "Structure and function of the blood-brain barrier," Neurobiology of Disease, vol. 37, no. 1, pp. 13-25, 2010. 
[6] J. Lee, M. C. Grabb, G. J. Zipfel, and D. W. Choi, "Brain tissue responses to ischemia," The Journal of Clinical Investigation, vol. 106, no. 6, pp. 723-731, 2000.

[7] J. P. MacManus, A. M. Buchan, I. E. Hill, I. Rasquinha, and E. Preston, "Global ischemia can cause DNA fragmentation indicative of apoptosis in rat brain," Neuroscience Letters, vol. 164, no. 1-2, pp. 89-92, 1993.

[8] S. Kihara, T. Shiraishi, S. Nakagawa, K. Toda, and K. Tabuchi, "Visualization of DNA double strand breaks in the gerbil hippocampal CA1 following transient ischemia," Neuroscience Letters, vol. 175, no. 1-2, pp. 133-136, 1994.

[9] G. M. Yan, R. P. Irwin, S. Z. Lin, M. Weller, K. A. Wood, and S. M. Paul, "Diphenylhydantoin induces apoptotic cell death of cultured rat cerebellar granule neurons," Journal of Pharmacology and Experimental Therapeutics, vol. 274, no. 2, pp. 983-990, 1995.

[10] F. C. Wilson, J. Harpur, T. Watson, and J. I. Morrow, "Adult survivors of severe cerebral hypoxia-case series survey and comparative analysis," NeuroRehabilitation, vol. 18, no. 4, pp. 291-298, 2003.

[11] H.-L. Hsieh and C.-M. Yang, "Role of redox signaling in neuroinflammation and neurodegenerative diseases," BioMed Research International, vol. 2013, Article ID 484613, 18 pages, 2013.

[12] J. Li, O. Wuliji, W. Li, Z. G. Jiang, and H. A. Ghanbari, "Oxidative stress and neurodegenerative disorders," International Journal of Molecular Sciences, vol. 14, no. 12, pp. 24438-24475, 2013.

[13] X. Wang, W. Wang, L. Li, G. Perry, H. G. Lee, and X. Zhu, "Oxidative stress and mitochondrial dysfunction in Alzheimer's disease," Biochimica et Biophysica Acta, vol. 1842, no. 8, pp. 1240-1247, 2013.

[14] M. H. Yan, X. Wang, and X. Zhu, "Mitochondrial defects and oxidative stress in Alzheimer disease and Parkinson disease," Free Radical Biology and Medicine, vol. 62, pp. 90-101, 2013.

[15] W. Paschen, "Role of calcium in neuronal cell injury: which subcellular compartment is involved?" Brain Research Bulletin, vol. 53, no. 4, pp. 409-413, 2000.

[16] P. H. Chan, "Reactive oxygen radicals in signaling and damage in the ischemic brain," Journal of Cerebral Blood Flow and Metabolism, vol. 21, no. 1, pp. 2-14, 2001.

[17] C. Iadecola and M. Alexander, "Cerebral ischemia and inflammation," Current Opinion in Neurology, vol. 14, no. 1, pp. 89-94, 2001.

[18] M. A. Petty and J. G. Wettstein, "Elements of cerebral microvascular ischaemia," Brain Research Reviews, vol. 36, no. 1, pp. 2334, 2001.

[19] H. S. Noh, Y. Hah, R. Nilufar et al., "Acetoacetate protects neuronal cells from oxidative glutamate toxicity," Journal of Neuroscience Research, vol. 83, no. 4, pp. 702-709, 2006.

[20] B. Halliwell, "Free radicals, antioxidants, and human disease: curiosity, cause, or consequence?” The Lancet, vol. 344, no. 8924, pp. 721-724, 1994.

[21] T. Sugawara and P. H. Chan, "Reactive oxygen radicals and pathogenesis of neuronal death after cerebral ischemia," Antioxidants and Redox Signaling, vol. 5, no. 5, pp. 597-607, 2003.

[22] T. M. Millar, V. Phan, and L. A. Tibbles, "ROS generation in endothelial hypoxia and reoxygenation stimulates MAP kinase signaling and kinase-dependent neutrophil recruitment," Free Radical Biology and Medicine, vol. 42, no. 8, pp. 1165-1177, 2007.

[23] J. A. McCubrey, M. M. LaHair, and R. A. Franklin, "Reactive oxygen species-induced activation of the MAP kinase signaling pathways," Antioxidants and Redox Signaling, vol. 8, no. 9-10, pp. 1775-1789, 2006.

[24] M. Torres and H. J. Forman, "Redox signaling and the MAP kinase pathways," BioFactors, vol. 17, no. 1-4, pp. 287-296, 2003.

[25] M. A. Bogoyevitch, J. Gillespie-Brown, A. J. Ketterman et al., "Stimulation of the stress-activated mitogen-activated protein kinase subfamilies in perfused heart: $\mathrm{p} 38 / \mathrm{RK}$ mitogen-activated protein kinases and c-Jun $\mathrm{N}$-terminal kinases are activated by ischemia/reperfusion," Circulation Research, vol. 79, no. 2, pp. 162-173, 1996.

[26] K. R. Laderoute and K. A. Webster, "Hypoxia/reoxygenation stimulates Jun kinase activity through redox signaling in cardiac myocytes," Circulation Research, vol. 80, no. 3, pp. 336-344, 1997.

[27] Z. Chen, T. B. Gibson, F. Robinson et al., "MAP kinases," Chemical Reviews, vol. 101, no. 8, pp. 2449-2476, 2001.

[28] J. M. Kyriakis and J. Avruch, "Sounding the alarm: protein kinase cascades activated by stress and inflammation," The Journal of Biological Chemistry, vol. 271, no. 40, pp. 24313-24316, 1996.

[29] P. Rockwell, J. Martinez, L. Papa, and E. Gomes, "Redox regulates COX-2 upregulation and cell death in the neuronal response to cadmium," Cellular Signalling, vol.16, no. 3, pp. 343353, 2004.

[30] D. J. Li, T. Zhao, R. J. Xin, Y. Y. Wang, Y. B. Fei, and F. M. Shen, "Activation of alpha7 nicotinic acetylcholine receptor protects against oxidant stress damage through reducing vascular peroxidase-1 in a JNK signaling-dependent manner in endothelial cells," Cellular Physiology and Biochemistry, vol. 33, no. 2, pp. 468-478, 2014.

[31] S. J. Harper and P. Lograsso, "Signalling for survival and death in neurones: the role of stress-activated kinases, JNK and p38," Cellular Signalling, vol. 13, no. 5, pp. 299-310, 2001.

[32] K. Nozaki, M. Nishimura, and N. Hashimoto, "Mitogenactivated protein kinases and cerebral ischemia," Molecular Neurobiology, vol. 23, no. 1, pp. 1-19, 2001.

[33] N. J. Abbott, "Astrocyte-endothelial interactions and bloodbrain barrier permeability," Journal of Anatomy, vol. 200, no. 6, pp. 629-638, 2002.

[34] P. Ballabh, A. Braun, and M. Nedergaard, "The blood-brain barrier: an overview: Structure, regulation, and clinical implications," Neurobiology of Disease, vol. 16, no. 1, pp. 1-13, 2004.

[35] M. Furuse, T. Hirase, M. Itoh, A. Nagafuchi, S. Yonemura, and S. Tsukita, "Occludin: a novel integral membrane protein localizing at tight junctions," Journal of Cell Biology, vol. 123, no. 6, pp. 1777-1788, 1993.

[36] M. Furuse, K. Fujita, T. Hiiragi, K. Fujimoto, and S. Tsukita, "Claudin-1 and -2: novel integral membrane proteins localizing at tight junctions with no sequence similarity to occludin," Journal of Cell Biology, vol. 141, no. 7, pp. 1539-1550, 1998.

[37] M. Furuse, H. Sasaki, and S. Tsukita, "Manner of interaction of heterogeneous claudin species within and between tight junction strands," Journal of Cell Biology, vol. 147, no. 4, pp. 891903, 1999.

[38] K. S. Mark and T. P. Davis, "Cerebral microvascular changes in permeability and tight junctions induced by hypoxiareoxygenation," American Journal of Physiology: Heart and Circulatory Physiology, vol. 282, no. 4, pp. H1485-H1494, 2002.

[39] K. A. Witt, K. S. Mark, S. Hom, and T. P. Davis, "Effects of hypoxia-reoxygenation on rat blood-brain barrier permeability and tight junctional protein expression," American Journal of Physiology-Heart and Circulatory Physiology, vol. 285, no. 6, pp. H2820-H2831, 2003. 
[40] K. S. Mark, A. R. Burroughs, R. C. Brown, J. D. Huber, and T. P. Davis, "Nitric oxide mediates hypoxia-induced changes in paracellular permeability of cerebral microvasculature," The American Journal of Physiology: Heart and Circulatory Physiology, vol. 286, no. 1, pp. H174-H180, 2004.

[41] S. D. Croll, J. H. Goodman, and H. E. Scharfman, "Vascular Endothelial Growth Factor (VEGF) in seizures: a double-edged sword," Advances in Experimental Medicine and Biology, vol. 548, pp. 57-68, 2004.

[42] D. H. Dobrogowska, A. S. Lossinsky, M. Tarnawski, and A. W. Vorbrodt, "Increased blood-brain barrier permeability and endothelial abnormalities induced by vascular endothelial growth factor," Brain Cell Biology, vol. 27, no. 3, pp. 163-173, 1998.

[43] Z. G. Zhang, L. Zhang, Q. Jiang et al., "VEGF enhances angiogenesis and promotes blood-brain barrier leakage in the ischemic brain," Journal of Clinical Investigation, vol. 106, no. 7, pp. 829-838, 2000.

[44] H. F. Dvorak, J. A. Nagy, D. Feng et al., "Vascular permeability factor/vascular endothelial growth factor and the significance of microvascular hyperpermeability in angiogenesis," Current Topics in Microbiology and Immunology, vol. 237, pp. 97-132, 1999.

[45] B. Poeggeler, S. Saarela, R. J. Reiter et al., "Melatonin—a highly potent endogenous radical scavenger and electron donor: new aspects of the oxidation chemistry of this indole accessed in vitro," Annals of the New York Academy of Sciences, vol. 738, pp. 419-420, 1994.

[46] F. Dupuis, O. Régrigny, J. Atkinson et al., "Impact of treatment with melatonin on cerebral circulation in old rats," The British Journal of Pharmacology, vol. 141, no. 3, pp. 399-406, 2004.

[47] A. Wakatsuki, Y. Okatani, C. Izumiya, and N. Ikenoue, "Melatonin protects against ischemia and reperfusion-induced oxidative lipid and DNA damage in fetal rat brain," Journal of Pineal Research, vol. 26, no. 3, pp. 147-152, 1999.

[48] M. D. Ginsberg and R. Busto, "Rodent models of cerebral ischemia," Stroke, vol. 20, no. 12, pp. 1627-1642, 1989.

[49] C. Harms, M. Lautenschlager, A. Bergk et al., "Melatonin is protective in necrotic but not in caspase-dependent, free radicalindependent apoptotic neuronal cell death in primary neuronal cultures," The FASEB Journal, vol. 14, no. 12, pp. 1814-1824, 2000.

[50] Z. Pei and R. T. F. Cheung, "Melatonin protects SHSY5Y neuronal cells but not cultured astrocytes from ischemia due to oxygen and glucose deprivation," Journal of Pineal Research, vol. 34, no. 3, pp. 194-201, 2003.

[51] D. Lv, P. Cui, S. Yao, Y. Xu, and Z. Yang, "Melatonin inhibits the expression of vascular endothelial growth factor in pancreatic cancer cells," Chinese Journal of Cancer Research, vol. 24, no. 4, pp. 310-316, 2012.

[52] M. Dai, P. Cui, M. Yu, J. Han, H. Li, and R. Xiu, "Melatonin modulates the expression of VEGF and HIF-1 $\alpha$ induced by $\mathrm{CoCl} 2$ in cultured cancer cells," Journal of Pineal Research, vol. 44, no. 2, pp. 121-126, 2008.

[53] P. Lissoni, F. Rovelli, F. Malugani, R. Bucovec, A. Conti, and G. J. M. Maestroni, "Anti-angiogenic activity of melatonin in advanced cancer patients," Neuroendocrinology Letters, vol. 22, no. 1, pp. 45-47, 2001.

[54] H.-J. Jung, Y.-H. Jeon, K. K. Bokara et al., "Agmatine promotes the migration of murine brain endothelial cells via multiple signaling pathways," Life Sciences, vol. 92, no. 1, pp. 42-50, 2013.

[55] Z. Y. Mei, C. M. Chin, J. C. Yoon et al., "Agmatine inhibits matrix metalloproteinase-9 via endothelial nitric oxide synthase in cerebral endothelial cells," Neurological Research, vol. 29, no. 7, pp. 749-754, 2007.

[56] K. K. Bokara, K. H. Kwon, Y. Nho, W. T. Lee, K. A. Park, and J. E. Lee, "Retroviral expression of arginine decarboxylase attenuates oxidative burden in mouse cortical neural stem cells," Stem Cells and Development, vol. 20, no. 3, pp. 527-537, 2011.

[57] S. Hong, C. Y. Kim, J. E. Lee, and G. J. Seong, "Agmatine protects cultured retinal ganglion cells from tumor necrosis factor-alpha-induced apoptosis," Life Sciences, vol. 84, no. 1-2, pp. 28-32, 2009.

[58] S. K. Ahn, S. Hong, Y. M. Park, W. T. Lee, K. A. Park, and J. E. Lee, "Effects of agmatine on hypoxic microglia and activity of nitric oxide synthase," Brain Research, vol. 1373, pp. 48-54, 2011.

[59] J. A. Royall and H. Ischiropoulos, "Evaluation of 2,7'dichlorofluorescin and dihydrorhodamine 123 as fluorescent probes for intracellular $\mathrm{H}_{2} \mathrm{O}_{2}$ in cultured endothelial cells," Archives of Biochemistry and Biophysics, vol. 302, no. 2, pp. 348355, 1993.

[60] C. Nyakas, B. Buwalda, and P. G. M. Luiten, "Hypoxia and brain development," Progress in Neurobiology, vol. 49, no. 1, pp. 1-51, 1996.

[61] J. Zhou, H. Kong, X. Hua, M. Xiao, J. Ding, and G. Hu, "Altered blood-brain barrier integrity in adult aquaporin-4 knockout mice," NeuroReport, vol. 19, no. 1, pp. 1-5, 2008.

[62] L. L. Rubin and J. M. Staddon, "The cell biology of the bloodbrain barrier," Annual Review of Neuroscience, vol. 22, pp. 11-28, 1999.

[63] G. J. del Zoppo, R. von Kummer, and G. F. Hamann, "Ischaemic damage of brain microvessels: inherent risks for thrombolytic treatment in stroke," Journal of Neurology Neurosurgery and Psychiatry, vol. 65, no. 1, pp. 1-9, 1998.

[64] R. Hardeland, "Antioxidative protection by melatonin: multiplicity of mechanisms from radical detoxification to radical avoidance," Endocrine, vol. 27, no. 2, pp. 119-130, 2005.

[65] G. Wu, R. L. Xue, J. R. Lv, W. Li, and X. M. Lei, "Fas and TNFR1 expressions after cerebral ischemia and reperfusion in rats: association with cell apoptosis and the effects of Bcl-2 overexpression," Journal of Southern Medical University, vol. 31, no. 8, pp. 1298-1303, 2011.

[66] V. Li, T. Brustovetsky, and N. Brustovetsky, "Role of cyclophilin D-dependent mitochondrial permeability transition in glutamate-induced calcium deregulation and excitotoxic neuronal death," Experimental Neurology, vol. 218, no. 2, pp. 171-182, 2009.

[67] P. Lipton, "Ischemic cell death in brain neurons," Physiological Reviews, vol. 79, no. 4, pp. 1431-1568, 1999.

[68] A. V. Andjelkovic, S. M. Stamatovic, and R. F. Keep, "The protective effects of preconditioning on cerebral endothelial cells in vitro," Journal of Cerebral Blood Flow and Metabolism, vol. 23, no. 11, pp. 1348-1355, 2003.

[69] M. I. Cervantes, P. M. de Oca Balderas, J. de Jesús GutiérrezBaños et al., "Comparison of antioxidant activity of hydroethanolic fresh and aged garlic extracts and their effects on cerebral ischemia," Food Chemistry, vol. 140, no. 1-2, pp. 343352, 2013.

[70] X.-C. Wang, Y.-C. Zhang, N. Chatterjie, I. Grundke-Iqbal, K. Iqbal, and J. Wang, "Effect of melatonin and melatonylvalpromide on $\beta$-amyloid and neurofilaments in N2a cells," Neurochemical Research, vol. 33, no. 6, pp. 1138-1144, 2008.

[71] J. Li, H. Yin, X. Gu, Y. Zhou, W. Zhang, and Y. Qin, "Melatonin protects liver from intestine ischemia reperfusion injury in rats," 
World Journal of Gastroenterology, vol. 14, no. 48, pp. 7392-7396, 2008.

[72] J. Wang, J. Shen, Q. Gao et al., "Ischemic postconditioning protects against global cerebral ischemia/reperfusion-induced injury in rats," Stroke, vol. 39, no. 3, pp. 983-990, 2008.

[73] Y. C. Li, H. J. Lin, J. H. Yang et al., "Baicalein-induced apoptosis via endoplasmic reticulum stress through elevations of reactive oxygen species and mitochondria dependent pathway in mouse-rat hybrid retina ganglion cells (N18)," Neurochemical Research, vol. 34, no. 3, pp. 418-429, 2009.

[74] S. Ozbal, B. U. Ergur, G. Erbil, I. Tekmen, A. Bagryank, and Z. Cavdar, "The effects of $\alpha$-lipoic acid against testicular ischemiareperfusion injury in rats," The Scientific World Journal, vol. 2012, Article ID 489248, 8 pages, 2012.

[75] R. J. Reiter, "Antioxidant actions of melatonin.," Advances in pharmacology, vol. 38, pp. 103-117, 1997.

[76] F. Tütünculer, S. Eskiocak, Ü. N. Başaran, G. Ekuklu, S. Ayvaz, and Ü. Vatansever, "The protective role of melatonin in experimental hypoxic brain damage," Pediatrics International, vol. 47, no. 4, pp. 434-439, 2005.

[77] D. Tan, R. J. Reiter, L. C. Manchester et al., "Chemical and physical properties and potential mechanisms: melatonin as a broad spectrum antioxidant and free radical scavenger," Current Topics in Medicinal Chemistry, vol. 2, no. 2, pp. 181-197, 2002.

[78] Ö. Çelik and M. Naziroǧlu, "Melatonin modulates apoptosis and TRPM2 channels in transfected cells activated by oxidative stress," Physiology \& Behavior, vol. 107, no. 3, pp. 458-465, 2012.

[79] P. D. Ray, B. W. Huang, and Y. Tsuji, "Reactive oxygen species (ROS) homeostasis and redox regulation in cellular signaling," Cellular Signalling, vol. 24, no. 5, pp. 981-990, 2012.

[80] E. Kubo, N. Miyoshi, M. Fukuda, and Y. Akagi, "Cataract formation through the polyol pathway is associated with free radical production," Experimental Eye Research, vol. 68, no. 4, pp. 457-464, 1999.

[81] Y. J. Lim, S. Zheng, and Z. Zuo, "Morphine preconditions purkinje cells against cell death under in vitro simulated ischemia-reperfusion conditions," Anesthesiology, vol. 100, no. 3, pp. 562-568, 2004.

[82] M. I. C. Alonso-Vale, S. Andreotti, S. B. Peres et al., "Melatonin enhances leptin expression by rat adipocytes in the presence of insulin," American Journal of Physiology-Endocrinology and Metabolism, vol. 288, no. 4, pp. E805-E812, 2005.

[83] R. E. Hartman, J. M. Lee, G. J. Zipfel, and D. F. Wozniak, "Characterizing learning deficits and hippocampal neuron loss following transient global cerebral ischemia in rats," Brain Research, vol. 1043, no. 1-2, pp. 48-56, 2005.

[84] K. Morita, H. Sasaki, K. Fujimoto, M. Furuse, and S. Tsukita, "Claudin-11/OSP-based tight junctions of myelin sheaths in brain and Sertoli cells in testis," Journal of Cell Biology, vol. 145, no. 3, pp. 579-588, 1999.

[85] S. Liebner, A. Fischmann, G. Rascher et al., "Claudin-1 and claudin-5 expression and tight junction morphology are altered in blood vessels of human glioblastoma multiforme," Acta Neuropathologica, vol. 100, no. 3, pp. 323-331, 2000.

[86] S. Liebner, U. Kniesel, H. Kalbacher, and H. Wolburg, "Correlation of tight junction morphology with the expression of tight junction proteins in blood-brain barrier endothelial cells," European Journal of Cell Biology, vol. 79, no. 10, pp. 707-717, 2000.

[87] A. Lippoldt, U. Kniesel, S. Liebner et al., "Structural alterations of tight junctions are associated with loss of polarity in stroke-prone spontaneously hypertensive rat blood-brain barrier endothelial cells," Brain Research, vol. 885, no. 2, pp. 251$261,2000$.

[88] T. Koto, K. Takubo, S. Ishida et al., "Hypoxia disrupts the barrier function of neural blood vessels through changes in the expression of claudin-5 in endothelial cells," The American Journal of Pathology, vol. 170, no. 4, pp. 1389-1397, 2007.

[89] R. Tao, J. Huang, X. Shao et al., "Ischemic injury promotes Keapl nitration and disturbance of antioxidative responses in endothelial cells: a potential vasoprotective effect of melatonin," Journal of Pineal Research, vol. 54, no. 3, pp. 271-281, 2013.

[90] T. J. Abbruscato and T. P. Davis, "Protein expression of brain endothelial cell E-cadherin after hypoxia/aglycemia: influence of astrocyte contact," Brain Research, vol. 842, no. 2, pp. 277286, 1999.

[91] C. Chryssanthou, T. Palaia, G. Goldstein, and R. Stenger, "Increase in blood-brain barrier permeability by altitude decompression," Aviation Space and Environmental Medicine, vol. 58, no. 11, pp. 1082-1086, 1987.

[92] H. J. Schoch, S. Fischer, and H. H. Marti, "Hypoxia-induced vascular endothelial growth factor expression causes vascular leakage in the brain," Brain, vol. 125, part 11, pp. 2549-2557, 2002.

[93] K. Hayashi, S. Nakao, R. Nakaoke, S. Nakagawa, N. Kitagawa, and M. Niwa, "Effects of hypoxia on endothelial/pericytic coculture model of the blood-brain barrier," Regulatory Peptides, vol. 123, no. 1-3, pp. 77-83, 2004.

[94] E. J. Battegay, "Angiogenesis: mechanistic insights, neovascular diseases, and therapeutic prospects," Journal of Molecular Medicine, vol. 73, no. 7, pp. 333-346, 1995.

[95] M. Milkiewicz, E. Ispanovic, J. L. Doyle, and T. L. Haas, "Regulators of angiogenesis and strategies for their therapeutic manipulation," International Journal of Biochemistry and Cell Biology, vol. 38, no. 3, pp. 333-357, 2006.

[96] G. L. Semenza, "Hydroxylation of HIF-1: oxygen sensing at the molecular level," Physiology, vol. 19, no. 4, pp. 176-182, 2004.

[97] J. Jośko and M. Mazurek, “Transcription factors having impact on vascular endothelial growth factor (VEGF) gene expression in angiogenesis," Medical Science Monitor, vol. 10, no. 4, pp. RA89-RA98, 2004.

[98] W. G. Mayhan, "VEGF increases permeability of the bloodbrain barrier via a nitric oxide synthase/cGMP-dependent pathway," American Journal of Physiology-Cell Physiology, vol. 276, no. 5, part 1, pp. C1148-C1153, 1999.

[99] P. P. Young, C. R. Fantz, and M. S. Sands, "VEGF disrupts the neonatal blood-brain barrier and increases life span after nonablative BMT in a murine model of congenital neurodegeneration caused by a lysosomal enzyme deficiency," Experimental Neurology, vol. 188, no. 1, pp. 104-114, 2004.

[100] P. Pichiule, J. C. Chávez, K. Xu, and J. C. Lamanna, "Vascular endothelial growth factor upregulation in transient global ischemia induced by cardiac arrest and resuscitation in rat brain," Molecular Brain Research, vol. 74, no. 1-2, pp. 83-90, 1999.

[101] A. D. Sinor, S. M. Irvin, C. S. Cobbs, J. Chen, S. H. Graham, and D. A. Greenberg, "Hypoxic induction of vascular endothelial growth factor (VEGF) protein in astroglial cultures," Brain Research, vol. 812, no. 1-2, pp. 289-291, 1998.

[102] R. Walter, M. Maggiorini, U. Scherrer, J. Contesse, and W. H. Reinhart, "Effects of high-altitude exposure on vascular endothelial growth factor levels in man," European Journal of Applied Physiology, vol. 85, no. 1-2, pp. 113-117, 2001. 
[103] D. O. Bates and S. J. Harper, "Regulation of vascular permeability by vascular endothelial growth factors," Vascular Pharmacology, vol. 39, no. 4-5, pp. 225-237, 2002.

[104] M. Ersahin, H. Z. Toklu, Ş. Çetinel, M. Yüksel, B. Ç. Yèen, and G. Şener, "Melatonin reduces experimental subarachnoid hemorrhage-induced oxidative brain damage and neurological symptoms," Journal of Pineal Research, vol. 46, no. 3, pp. 324$332,2009$.

[105] H.-Y. Chen, T.-Y. Chen, M.-Y. Lee et al., "Melatonin decreases neurovascular oxidative/nitrosative damage and protects against early increases in the blood-brain barrier permeability after transient focal cerebral ischemia in mice," Journal of Pineal Research, vol. 41, no. 2, pp. 175-182, 2006.

[106] C. Kaur, V. Sivakumar, J. Lu, F. R. Tang, and E. A. Ling, "Melatonin attenuates hypoxia-induced ultrastructural changes and increased vascular permeability in the developing hippocampus," Brain Pathology, vol. 18, no. 4, pp. 533-547, 2008.

[107] Y. Zhang, Q. Liu, F. Wang et al., "Melatonin antagonizes hypoxia-mediated glioblastoma cell migration and invasion via inhibition of HIF-1 $\alpha$," Journal of Pineal Research, vol. 55, no. 2, pp. 121-130, 2013.

[108] C. Kaur, V. Sivakumar, J. Lu, and E. A. Ling, "Increased vascular permeability and nitric oxide production in response to hypoxia in the pineal gland," Journal of Pineal Research, vol. 42, no. 4, pp. 338-349, 2007.

[109] S. Maddika, S. R. Ande, S. Panigrahi et al., "Cell survival, cell death and cell cycle pathways are interconnected: implications for cancer therapy," Drug Resistance Updates, vol. 10, no. 1-2, pp. 13-29, 2007.

[110] B. Wang, J. Shravah, H. Luo, K. Raedschelders, D. D. Y. Chen, and D. M. Ansley, "Propofol protects against hydrogen peroxide-induced injury in cardiac $\mathrm{H} 9 \mathrm{c} 2$ cells via Akt activation and Bcl-2 up-regulation," Biochemical and Biophysical Research Communications, vol. 389, no. 1, pp. 105-111, 2009.

[111] R. Kimura, M. Okouchi, H. Fujioka et al., "Glucagon-like peptide-1 (GLP-1) protects against methylglyoxal-induced PC12 cell apoptosis through the PI3K/Akt/mTOR/GCLc/redox signaling pathway," Neuroscience, vol. 162, no. 4, pp. 1212-1219, 2009.

[112] S. Lee, J. Shin, Y. Hong et al., "Beneficial effects of melatonin on stroke-induced muscle atrophy in focal cerebral ischemic rats," Laboratory Animal Research, vol. 28, no. 1, pp. 47-54, 2012.

[113] T. Jiang, Q. Chang, Z. Zhao et al., "Melatonin-mediated cytoprotection against hyperglycemic injury in Müller cells," PLoS ONE, vol. 7, no. 12, Article ID e50661, 2012.

[114] S. H. Lee, W. Chun, P. J. Kong et al., "Sustained activation of Akt by melatonin contributes to the protection against kainic acid-induced neuronal death in hippocampus," Journal of Pineal Research, vol. 40, no. 1, pp. 79-85, 2006.

[115] P. Kong, J. Byun, S. Lim et al., "Melatonin induees Akt phosphorylation through Melatonin receptor- and PI3K-dependent pathways in primary astrocytes," Korean Journal of Physiology and Pharmacology, vol. 12, no. 2, pp. 37-41, 2008.

[116] B. D. Manning and L. C. Cantley, "AKT/PKB signaling: navigating downstream," Cell, vol. 129, no. 7, pp. 1261-1274, 2007.

[117] H. Zhou, L. Liu, Y. Zhang et al., "Glutathione prevents free fatty acids-induced oxidative stress and apoptosis in human brain vascular endothelial cells through Akt pathway," CNS Neuroscience and Therapeutics, vol. 19, no. 4, pp. 252-261, 2013.

[118] I. Shiojima and K. Walsh, "Role of Akt signaling in vascular homeostasis and angiogenesis," Circulation Research, vol. 90, no. 12, pp. 1243-1250, 2002.
[119] G. Song, G. Ouyang, and S. Bao, "The activation of Akt/PKB signaling pathway and cell survival," Journal of Cellular and Molecular Medicine, vol. 9, no. 1, pp. 59-71, 2005.

[120] J. Bai, L. Dong, Z. Song et al., "The role of melatonin as an antioxidant in human lens epithelial cells," Free Radical Research, vol. 47, no. 8, pp. 635-642, 2013.

[121] Y. Zhang, X. Wang, H. Yang et al., "Kinase AKT controls innate immune cell development and function," Immunology, vol. 140, no. 2, pp. 143-152, 2013.

[122] B. A. Teicher, "Molecular targets and cancer therapeutics: discovery, development and clinical validation," Drug Resistance Updates, vol. 3, no. 2, pp. 67-73, 2000.

[123] Y. Huang, D. Wu, and W. Fan, "Protection of ginsenoside Rg1 on chondrocyte from IL-1beta-induced mitochondria-activated apoptosis through PI3K/Akt signaling," Molecular and Cellular Biochemistry, vol. 392, no. 1-2, pp. 249-257, 2014.

[124] X. Zhang, L. Bi, Y. Ye, and J. Chen, "Formononetin induces apoptosis in PC-3 prostate cancer cells through enhancing the $\mathrm{Bax} / \mathrm{Bcl}-2$ ratios and regulating the $\mathrm{p} 38 /$ Akt pathway," Nutrition and Cancer, vol. 66, no. 4, pp. 656-661, 2014.

[125] C. $\mathrm{Xu}, \mathrm{A} . \mathrm{Wu}, \mathrm{H}$. Zhu et al., "Melatonin is involved in the apoptosis and necrosis of pancreatic cancer cell line SW1990 via modulating of Bcl-2/Bax balance," Biomedicine and Pharmacotherapy, vol. 67, no. 2, pp. 133-139, 2013.

[126] M. Mohseni, E. Mihandoost, A. Shirazi, Z. Sepehrizadeh, J. T. Bazzaz, and M. Ghazi-Khansari, "Melatonin may play a role in modulation of bax and bcl-2 expression levels to protect rat peripheral blood lymphocytes from gamma irradiationinduced apoptosis," Mutation Research-Fundamental and Molecular Mechanisms of Mutagenesis, vol. 738-739, no. 1, pp. $19-27,2012$.

[127] F. M. Ho, S. H. Liu, C. S. Liau, P. J. Huang, and S. Y. Lin-Shiau, "High glucose-induced apoptosis in human endothelial cells is mediated by sequential activations of c-JUN $\mathrm{NH}_{2}$-terminal kinase and caspase-3," Circulation, vol. 101, no. 22, pp. 26182624, 2000.

[128] W. Takabe, R. Li, L. Ai, F. Yu, J. A. Berliner, and T. K. Hsiai, "Oxidized low-density lipoprotein-activated c-Jun NH2terminal kinase regulates manganese superoxide dismutase ubiquitination: implication for mitochondrial redox status and apoptosis," Arteriosclerosis, Thrombosis, and Vascular Biology, vol. 30, no. 3, pp. 436-441, 2010.

[129] G. Garin, J. Abe, A. Mohan et al., "Flow antagonizes TNF- $\alpha$ signaling in endothelial cells by inhibiting caspase-dependent PKCל processing," Circulation Research, vol. 101, no. 1, pp. 97105, 2007.

[130] H. M. Shen and Z. G. Liu, "JNK signaling pathway is a key modulator in cell death mediated by reactive oxygen and nitrogen species," Free Radical Biology and Medicine, vol. 40, no. 6, pp. 928-939, 2006.

[131] B. Cai, X. Li, Y. Wang et al., "Apoptosis of bone marrow mesenchymal stem cells caused by homocysteine via activating jnk signal," PLoS ONE, vol. 8, no. 5, Article ID e63561, 2013.

[132] W. S. Choi, S. Y. Yoon, T. H. Oh, E. J. Choi, K. L. O'Malley, and Y. J. Oh, "Two distinct mechanisms are involved in 6hydroxydopamine- and MPP+-induced dopaminergic neuronal cell death: role of caspases, ROS, and JNK," Journal of Neuroscience Research, vol. 57, no. 1, pp. 86-94, 1999.

[133] K. Chang, C. Hsu, S. Liu et al., "Cadmium induces apoptosis in pancreatic beta-cells through a mitochondria-dependent pathway: the role of oxidative stress-mediated c-Jun N-terminal 
kinase activation," PLoS ONE, vol. 8, no. 2, Article ID e54374, 2013.

[134] E. Shaulian and M. Karin, "AP-1 as a regulator of cell life and death," Nature Cell Biology, vol. 4, no. 5, pp. E131-E136, 2002.

[135] G. A. Rosenberg, "Matrix metalloproteinases in neuroinflammation," Glia, vol. 39, no. 3, pp. 279-291, 2002.

[136] Y. Gao, A. P. Signore, W. Yin et al., "Neuroprotection against focal ischemic brain injury by inhibition of c-Jun N-terminal kinase and attenuation of the mitochondrial apoptosissignaling pathway," Journal of Cerebral Blood Flow and Metabolism, vol. 25, no. 6, pp. 694-712, 2005.

[137] Q.-H. Guan, D.-S. Pei, Y.-Y. Zong, T.-L. Xu, and G.-Y. Zhang, "Neuroprotection against ischemic brain injury by a small peptide inhibitor of c-Jun N-terminal kinase (JNK) via nuclear and non-nuclear pathways," Neuroscience, vol. 139, no. 2, pp. 609-627, 2006.

[138] Q. H. Guan, D. S. Pei, X. M. Liu, X. T. Wang, T. L. Xu, and G. Y. Zhang, "Neuroprotection against ischemic brain injury by SP600125 via suppressing the extrinsic and intrinsic pathways of apoptosis," Brain Research, vol. 1092, no. 1, pp. 36-46, 2006.

[139] T. Borsellol, P. G. H. Clarkel, L. Hirt et al., "A peptide inhibitor of c-Jun N-terminal kinase protects against excitotoxicity and cerebral ischemia," Nature Medicine, vol. 9, no. 9, pp. 1180-1186, 2003. 


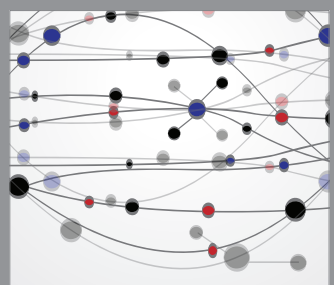

The Scientific World Journal
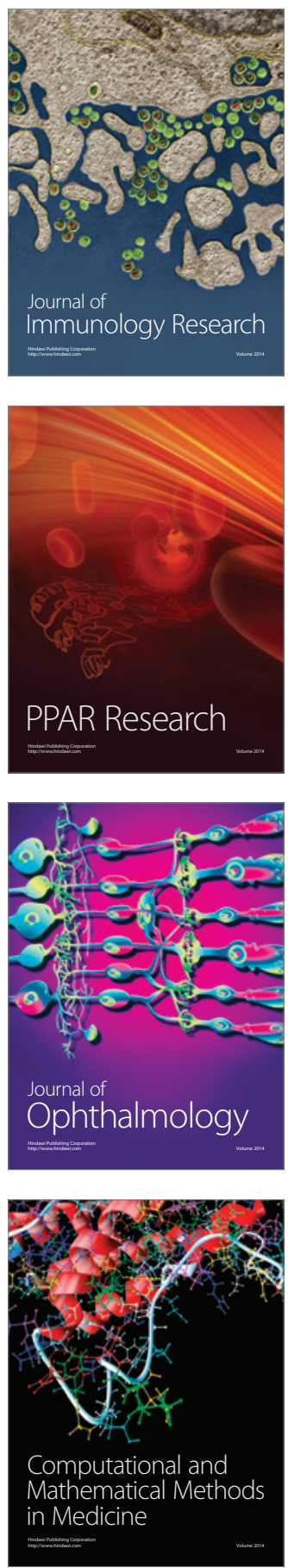

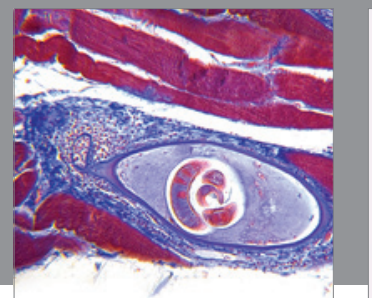

Gastroenterology

Research and Practice
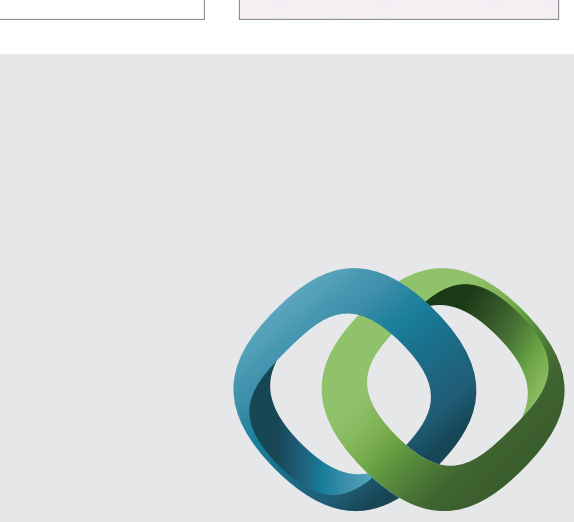

\section{Hindawi}

Submit your manuscripts at

http://www.hindawi.com
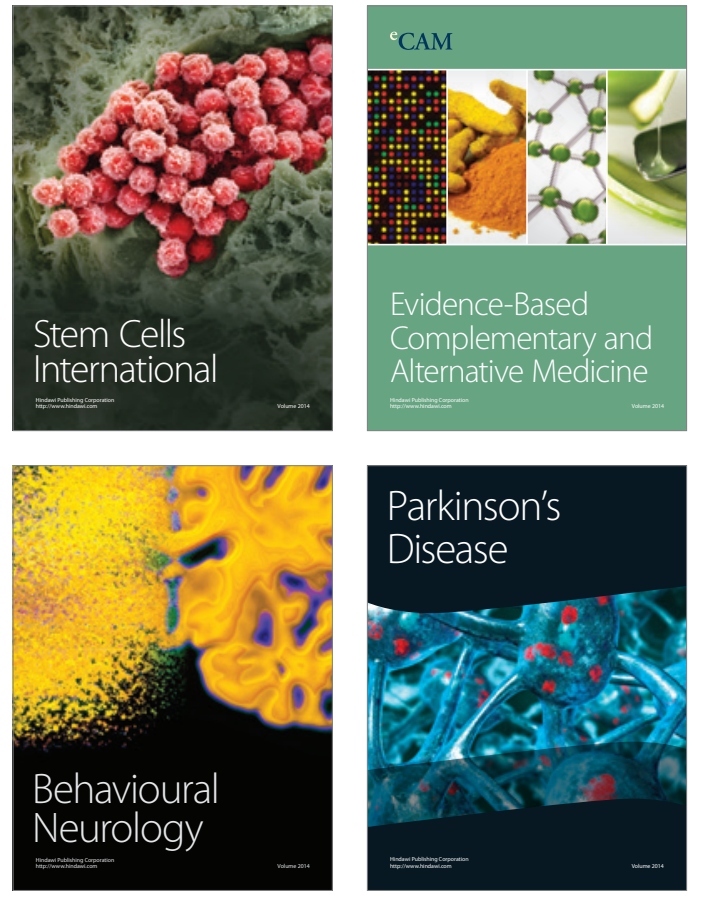
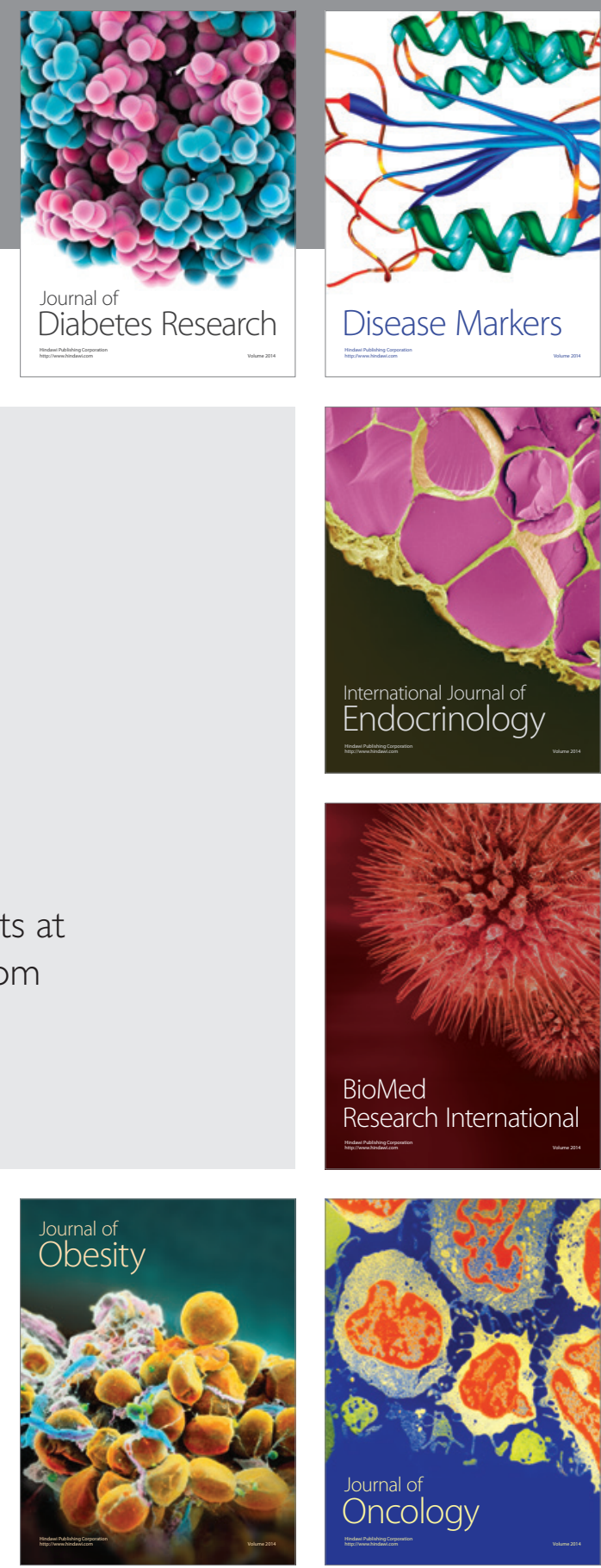

Disease Markers
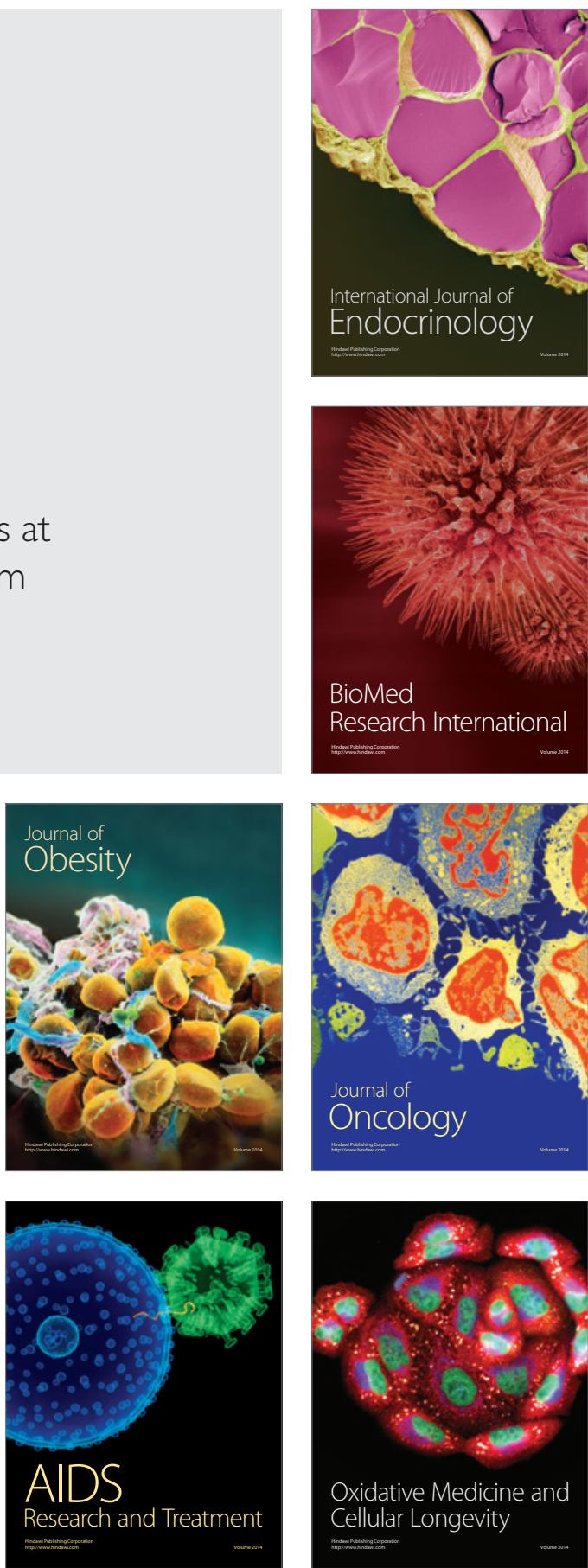